\title{
Decreased levels of regulatory $B$ cells in patients with acute pancreatitis: association with the severity of the disease
}

\author{
Liannv Qiu ${ }^{1}$, Yonglie Zhou ${ }^{1}$, Qinghua $\mathrm{Yu}^{1}$, Junde $\mathrm{Yu}^{1}$, Qian $\mathrm{Li}^{2}$ and Renhua Sun ${ }^{2}$ \\ ${ }^{1}$ Department of Clinical Laboratory, Zhejiang Provincial People's Hospital, People's Hospital of Hangzhou Medical College, \\ Hangzhou, 310004, China \\ ${ }^{2}$ Department of Intensive Care Unit, Zhejiang Provincial People's Hospital, People's Hospital of Hangzhou Medical College, \\ Hangzhou, 310004, China
}

Correspondence to: Liannv Qiu, email: qlv2012@126.com

Keywords: regulatory b cells; acute pancreatitis; interleukin-10; diagnostic utility

Received: January 26, 2017 Accepted: November 03, 2017 Epub: January 03, 2018 Published: November 16, 2018

Copyright: Qiu et al. This is an open-access article distributed under the terms of the Creative Commons Attribution License 3.0 (CC BY $3.0)$, which permits unrestricted use, distribution, and reproduction in any medium, provided the original author and source are credited.

\section{ABSTRACT}

Early stratification of the severity of acute pancreatitis (AP) is clinically important. Regulatory B cells have been found to be associated with disease activity of autoimmune diseases. However, the role of Regulatory B cells in AP remains unknown. We investigate the dynamic longitudinal changes in circulating IL-10-producing B cells $(B 10)$ and memory $C D 19+C D 24^{\text {hi }} C D 27^{\text {hi }}$ cells in patients with AP to evaluate

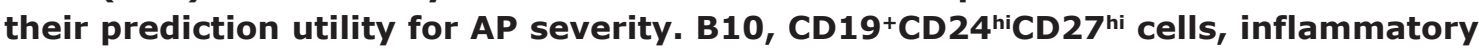
markers and cytokines were detected in patients with AP immediately after admission to the hospital (day 1), then on the third and seventh days. We observed decreases

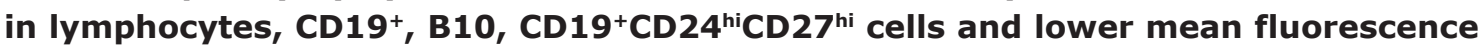
intensity (MFI) of CD80 and CD86 on B10 or CD19 ${ }^{+}$CD2 $4^{\text {hi }}$ CD2 $27^{\text {hi }}$ cells in patients with $A P$, especially in those with severe acute pancreatitis (SAP). CD19+CD24 ${ }^{\text {hi }} C D 27^{\text {hi }}$ cells from patients with AP suppressed the cytokine productions of $\mathrm{CD4}^{+} \mathrm{T}$ cells and CD14 ${ }^{+}$ monocytes, but had impaired ability to induce regulatory $\mathrm{T}$ cells response. B10 and CD19+CD24 ${ }^{\text {hi }} C D 27^{\text {hi }}$ cells significantly increased in patients with mild acute pancreatitis (MAP) from day 1 to day 7, whereas these indexes remained stable in patients with SAP. B10 or CD19 ${ }^{+C D 24} 4^{\text {hi }}$ CD27 ${ }^{\text {hi }}$ cells were negatively correlated with the severity index (APACHE II score), inflammatory markers (C-reactive protein, CD64 index), and cytokines (IL-6, IL-17, TNF-a). Furthermore, receiver operating characteristic (ROC) curve analysis revealed that $B 10$ and $C D 19^{+} C D 24^{\text {hi }} C D 27^{\text {hi }}$ cells could predict the development of SAP. Thus, the detection of B10 and CD19 ${ }^{+}$CD $24^{\text {hi }}$ CD2 $7^{\text {hi }}$ cells may be a practical way to improve the early assessment of AP severity.

\section{INTRODUCTION}

The severity and course of acute pancreatitis (AP) are difficult to evaluate by assessing the first symptoms and clinical signs alone. Although it is mostly self-limiting, approximately $20-30 \%$ of all patients will progress to a severe form, which has approximately a $5 \%$ mortality rate $[1,2]$. An early prediction of AP severity is important in the evaluation of the clinical prognosis and treatment. In a clinical setting, various methods have been used to predict AP severity, including the Acute Physiology and Chronic Health Evaluation (APACHE) II score, Ranson score, and

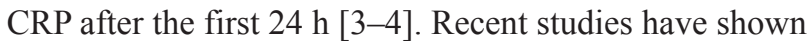

that CD64 index was correlated with disease severity in SAP and may act as a useful marker for the prediction of the development of SAP [5-6]. The expression of HLA-DR on monocytes was highly related to the effector functions of the monocytes. CD14 ${ }^{+} \mathrm{HLA}-\mathrm{DR}{ }^{\text {low/ }}$ cells, the myeloid-derived suppressor cells with immunosuppressive lymphocyte function, have also been shown to predict the development of organ failure and a fatal outcome [7]. However, these methods in the prediction of AP severity have limitations in the clinical practice. Research has thus focused on the search for novel biochemical markers that can predict AP severity in the initial $24 \mathrm{~h}$ following admission. 
At present, it is widely accepted that AP is an inflammatory disorder. As an inflammatory process, AP results in excessive leukocyte activation and increased migration of neutrophils to the inflamed area, with a consequent release of pro-inflammatory mediators including interleukins (IL-6, IL-8, IL-15, IL-33, and IL17), procalcitonin and tumor necrosis factor-a (TNF- $\alpha$ ) [813]. To maintain immune homeostasis, the body contains regulatory cells which secrete anti-inflammatory factors (e.g., IL-10, transforming growth factor $\beta$ (TGF- $\beta$ )) to limit the inflammation process [14]. Normally, the proand anti-inflammatory responses are maintained in a state of balance. In SAP, however, this balance is disrupted, and an abnormal activation of inflammatory cells leads to systemic inflammatory response syndrome (SIRS) and multiple organ dysfunction (MODS).

Studies have shown that $\mathrm{T}$ helper cells play critical roles in the pathogenesis of AP $[15,16]$, but the role of regulatory B cells remains unclear. Regulatory B cells are potent negative regulators of inflammation and autoimmune diseases via the release of IL-10 or TGF- $\beta$. $\mathrm{B} 10$ cells are now recognized as an important component of the immune system. Two B subsets including memory $\mathrm{CD} 19^{+} \mathrm{CD} 24^{\mathrm{hi}} \mathrm{CD} 27^{\mathrm{hi}}$ [17] and immature/transitional $\mathrm{CD} 19^{+} \mathrm{CD} 24^{\text {hi }} \mathrm{CD} 38^{\text {hi }} \mathrm{B}$ cells [18], both of which can secrete IL-10 in vitro depending on various stimulations, have been identified in humans. Human $\mathrm{CD} 19^{+} \mathrm{CD} 24^{\mathrm{hi}} \mathrm{CD} 38^{\mathrm{hi}}$ cells have been reported to suppress Th1 and Th17 cell differentiation through the production of IL-10 [19]. Carter NA found that, in humans, under conditions of pan-B cell depletion, including regulatory $\mathrm{B}$ cell depletion, the inflammatory response will be uncontrolled [20]. The aim of this study was to assess circulating B10 and memory $\mathrm{CD} 19^{+} \mathrm{CD} 24^{\text {hi }} \mathrm{CD} 27^{\text {hi }}$ cells among patients with AP of varying severity at the early phase of the disease (first 48 $\mathrm{h}$ from the onset of abdominal pain) and to evaluate their diagnostic utility for the prediction of AP severity.

\section{RESULTS}

\section{Decreased levels of $\mathrm{B} 10$ or $\mathrm{CD} 19^{+} \mathrm{CD} 24^{\mathrm{hi}} \mathrm{CD} 27^{\mathrm{hi}}$ cells in patients with $\mathrm{AP}$}

The numbers of leukocytes were significantly higher but the numbers of lymphocytes were significantly lower in patients with AP on admission than those of healthy individuals (all $P<0.001$ ), but no significant difference in the numbers of leukocytes and lymphocytes was observed between patients with MAP and SAP $(P=$ $0.0945, P=0.0514$, respectively, Table 1$)$. The frequencies and numbers of $\mathrm{CD} 19^{+}, \mathrm{B} 10$ and $\mathrm{CD} 19^{+} \mathrm{CD} 24^{\mathrm{hi}} \mathrm{CD} 27^{\mathrm{hi}}$ cells in patients with MAP and SAP on admission were below the corresponding frequencies and numbers in healthy individuals (all $P<0.001$ ). In addition, the numbers of $\mathrm{CD} 19^{+}, \mathrm{B} 10$ and $\mathrm{CD} 19^{+} \mathrm{CD} 24^{\mathrm{hi}} \mathrm{CD} 27^{\mathrm{hi}}$ cells in patients with SAP were significantly lower than those in patients with $\mathrm{MAP}(P=0.0198, P=0.0028, P=0.0313$, respectively, Figure 1A-1J).

\section{The lower MFI of CD80 and CD86 on B10 or CD19 ${ }^{+} \mathrm{CD}^{2} 4^{\text {hi }} \mathrm{CD} 27^{\text {hi }}$ cells in patients with $\mathrm{AP}$}

Because $\mathrm{B} 10$ and $\mathrm{CD} 19^{+} \mathrm{CD} 24^{\text {hi }} \mathrm{CD} 27^{\text {hi }}$ cells were significantly decreased in patients with AP, we investigated the expression of the activation markers CD80 and CD86 by immunofluorescence staining and flow cytometry to determine whether a difference was present in the activation status of $\mathrm{B} 10$ or $\mathrm{CD} 19^{+} \mathrm{CD} 24^{\mathrm{hi}} \mathrm{CD} 27^{\mathrm{hi}}$ cells between patients with AP and healthy individuals. We noticed that lower MFI of CD80 and CD86 on B10 or $\mathrm{CD} 19^{+} \mathrm{CD} 24^{\mathrm{hi}} \mathrm{CD} 27^{\mathrm{hi}}$ cells in patients with MAP and SAP was detected compared with that in healthy individuals (all $P<0.001$, Figure 2A, 2C, 2D, 2F, 2G, 2I, 2J, 2L); Similarly, the MFI of CD80 and CD86 on $\mathrm{B} 10$ or $\mathrm{CD} 19^{+} \mathrm{CD} 24^{\mathrm{hi}} \mathrm{CD} 27^{\mathrm{hi}}$ cells in patients with SAP was lower than that in patients with MAP $(P=0.029, P=$ $0.0067, P=0.028, P<0.001)$. However, the frequencies of $\mathrm{CD} 80$ and $\mathrm{CD} 86$ on $\mathrm{B} 10$ or $\mathrm{CD} 19^{+} \mathrm{CD} 24^{\mathrm{hi}} \mathrm{CD} 27^{\mathrm{hi}}$ cells were not different between patients with AP and healthy individuals (Figure 2B, 2E, 2H, 2K). Therefore, B10 and $\mathrm{CD} 19^{+} \mathrm{CD} 24^{\mathrm{hi}} \mathrm{CD} 27^{\mathrm{hi}}$ cells in patients with AP were in a low activation state.

\section{$\mathrm{CD}^{+}{ }^{+} \mathrm{CD} 24^{\text {hi }} \mathrm{CD} 27^{\text {hi }}$ cells from AP patients suppress the cytokine productions of $\mathrm{CD4}^{+} \mathrm{T}$ cells and $\mathrm{CD}^{+}{ }^{+}$monocytes, but have impaired ability to induce tregs response}

To investigate the functional properties of Bregs, $\mathrm{CD} 19^{+} \mathrm{CD} 24^{\text {hi }} \mathrm{CD} 27^{\text {hi }}$ cells were sorted from healthy individuals, five patients with MAP and five patients with SAP and co-cultured 1:1 with autologous $\mathrm{CD}^{+} \mathrm{CD} 25^{-} \mathrm{T}$ cells in the presence of anti-CD3 and anti-CD28, which has been demonstrated to stimulate $\mathrm{T}$ cells activation and up-regulate CD40L expression on T cells: CD40L is necessary for the activation of $\mathrm{B}$ cells to exert suppressive function. After $72 \mathrm{~h}$, we observed a slight, but significantly lower percentage of IFN- $\gamma$-, IL-17-and TNF- $\alpha$-producing $\mathrm{CD} 4^{+} \mathrm{T}$ cells when co-cultured with $\mathrm{CD} 19^{+} \mathrm{CD} 24^{\mathrm{hi}} \mathrm{CD} 27^{\mathrm{hi}}$ cells compared to $\mathrm{CD} 4^{+} \mathrm{CD} 25^{-} \mathrm{T}$ cells alone from patients with AP (Figure 3A-3C). Similarly, after the co-culture CD14 ${ }^{+}$HLA-DR - monocytes with $\mathrm{CD} 19^{+} \mathrm{CD} 24^{\text {hi }} \mathrm{CD} 27^{\text {hi }}$ cells from patients with AP, a statistically significant lower percentage of TNF- $\alpha$-producing CD14 ${ }^{+}$cells was shown when compared to CD14 HLA-DR- cells alone (Figure $3 \mathrm{G})$. More obvious suppression the cytokine productions of $\mathrm{CD}^{+} \mathrm{T}$ cells and $\mathrm{CD} 14^{+}$monocytes was observed in patients with SAP. But no obvious suppression the cytokine productions of $\mathrm{CD} 4^{+} \mathrm{T}$ cells and $\mathrm{CD} 14^{+}$monocytes was observed in healthy individuals.

After the co-culture $\mathrm{CD} 4{ }^{+} \mathrm{CD} 25^{+} \mathrm{T}$ cells with $\mathrm{CD} 19^{+} \mathrm{CD} 24^{\text {hi }} \mathrm{CD} 27^{\text {hi }}$ cells from patients with $\mathrm{AP}$, a 
Table 1: Characteristics of the patients with AP and healthy individuals

\begin{tabular}{lccc}
\hline & MAP & SAP & healthy individuals \\
\hline Number of patients & 46 & 17 & 21 \\
Median age in years (range) & $56(21-68)$ & $59(27-72)$ & $59(28-70)$ \\
Sex (male/female) & $27 / 17$ & $11 / 8$ & $10 / 11$ \\
Etiology & & & \\
Biliary & 15 & 7 & \\
Alcohol & 14 & 9 & \\
Other & 10 & 2 & \\
Unknown & 5 & 1 & \\
Mean APACHE II score & 1.27 & 14.33 & \\
Leukocytes $(\times 109 / \mathrm{L})$ & $12.3(4.2-14.2)$ & $14.6(8.94-21.0)$ & $1.84(1.24-2.89)$ \\
Lymphocytes $(\times 109 / \mathrm{L})$ & $1.06(0.42-1.56)$ & $0.66(0.16-1.39)$ & $46.1(35.1-70.3)$ \\
Lipase $(\mathrm{U} / \mathrm{L})$ & $125.5(57-189)$ & $311.7(87-411.2)$ & $2.31(2.12-2.49)$ \\
Amylase $(\mathrm{U} / \mathrm{L})$ & $107.6(57.0-164.8) 103.1$ & $(73.3-191.7)$ & $2.53(1.3-8.92)$ \\
Calcium( mmol/L) & $2.33(2.34-2.52)$ & $1.92(1.67-2.17)$ & \\
CRP $(\mathrm{pg} / \mathrm{mL})$ & $48.24(23.9-162.7)$ & $134.8(71.2-246.1)$ & 2 \\
Pancreatic necrosis & & 2 & \\
\hline
\end{tabular}

Note: APACHE: Acute Physiology and Chronic Health Evaluation; MAP: Mild acute pancreatitis, SAP: Severe acute pancreatitis. Data are presented as the median (range).

slight elevation of $\mathrm{CD} 4^{+} \mathrm{FoxP} 3^{+} \mathrm{T}$ cells was shown when compared to that in $\mathrm{CD} 4^{+} \mathrm{CD} 25^{+} \mathrm{T}$ cells alone (Figure 3D). We also analyzed the production of IL-10 and TGF- $\beta$ on $\mathrm{CD} 4^{+} \mathrm{CD} 25^{+} \mathrm{T}$ cells from patients with $\mathrm{AP}$ and found that $\mathrm{CD} 19^{+} \mathrm{CD} 24^{\text {hi }} \mathrm{CD} 27^{\text {hi }}$ cells increased the production of IL10 and TGF $\beta$ on $\mathrm{CD} 4^{+} \mathrm{CD} 25^{+} \mathrm{T}$ cells in patients with $\mathrm{AP}$ and healthy individuals (Figure 3E-3F). However, more obvious enhancement was found in healthy individuals, which suggested that the ability of $\mathrm{CD} 19^{+} \mathrm{CD} 24^{\mathrm{hi}} \mathrm{CD} 27^{\mathrm{hi}}$ cells to induce Tregs response was partly impaired.

\section{Elevated levels of Th17 cells and $\mathrm{CD4}^{+} \mathrm{CD}^{25}{ }^{\text {hi }} \mathrm{FoxP}^{+}$cells but decreased levels of Th1 cells in patients with AP}

We measured the numbers of Th1 $\left(\mathrm{CD} 3^{+} \mathrm{CD} 8\right.$-IFN$\left.\gamma^{+} \mathrm{IL}-17^{-}\right)$and Th17 (CD3 $\left.{ }^{+} \mathrm{CD} 8-\mathrm{IFN}-\gamma^{-} \mathrm{IL}-17^{+}\right)$cells and Tc1 $\left(\mathrm{CD}^{+}{ }^{+} \mathrm{CD}^{+} \mathrm{IFN}^{-} \gamma^{+} \mathrm{IL}-17^{-}\right)$and $\mathrm{Tc} 17 \quad\left(\mathrm{CD} 3^{+} \mathrm{CD} 8^{+} \mathrm{IFN}-\gamma\right.$ IL-17 $7^{+}$cells from patients with AP and healthy individuals as described in the Materials and Methods section (Figure 4A). The frequencies and numbers of Th17 cells were significantly higher in patients with MAP and SAP compared with healthy individuals, especially in those with $\mathrm{SAP}(P<0.001, P=$ $0.0004, P<0.001$, Figure 4B-4F). However, the frequencies and numbers of Th1 cells were lower in patients with SAP compared with healthy individuals $(P=0.0029, P=0.0064$, Figure 4D-4F). No difference in the frequencies and numbers of Tc1 cells and the numbers of Tc17 was observed in patients with AP compared with healthy individuals (Supplementary Figure 1A-1E). Only the frequencies of Tc17 cells were significantly higher in patients with SAP compared with healthy individuals $(P=0.0019)$.

The frequencies of $\mathrm{CD}^{+} \mathrm{CD} 25^{\text {hi }} \mathrm{Foxp}^{+}$Tregs were significantly higher in patients with MAP and SAP compared with healthy individuals, especially in those with SAP (all $P<0.001$ ). $\mathrm{CD} 4{ }^{+} \mathrm{CD} 25^{\text {hi }}$ Foxp $3^{+}$Tregs were significantly more numerous in patients with SAP compared with patients with MAP and healthy individuals $(P=0.0031, P=0.004$, Figure 4G-4J $)$.

\section{CD14 $^{+}{ }^{+}$LA-DR ${ }^{\text {low/- }}$ cells and CD64 index are elevated in patients with AP compared with healthy individuals}

The frequencies and numbers of CD14+HLA-DR ${ }^{\text {low- }}$ cells and CD64 index were significantly increased in patients with AP, especially those with SAP, on admission compared with healthy individuals (all $P<0.001$, Figure $5 \mathrm{~A}-5 \mathrm{E}$ ). Interestingly, when we compared MAP patients with healthy individuals, the frequencies and numbers of CD14 ${ }^{+}$HLA-DR ${ }^{\text {low/ }}$ cells and CD64 index also differed significantly between the 2 groups $(P<0.001, P<0.001$, $P=0.0034$ ).

\section{Serum cytokines except for IFN- $\gamma$ are increased in patients with $A P$}

We know that cytokines play a crucial role in the pathogenesis of AP as they drive the additional inflammatory response, which leads to tissue damages and 
A

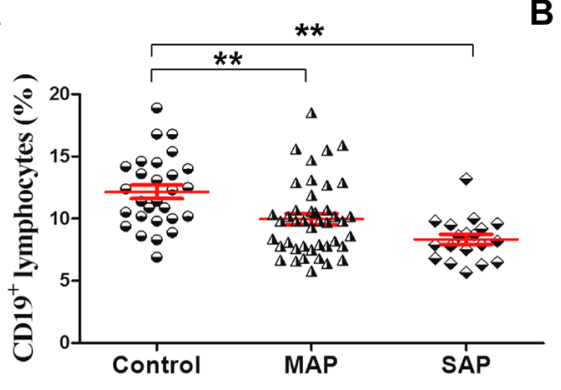

B

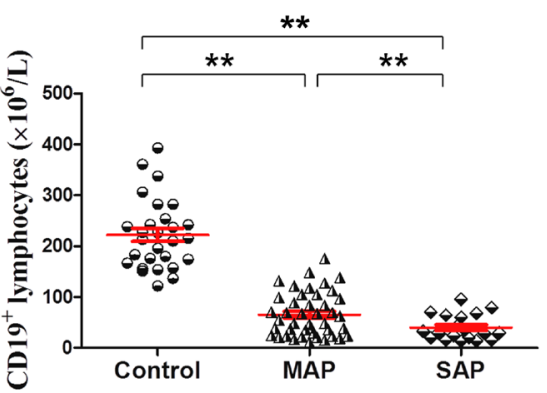

C

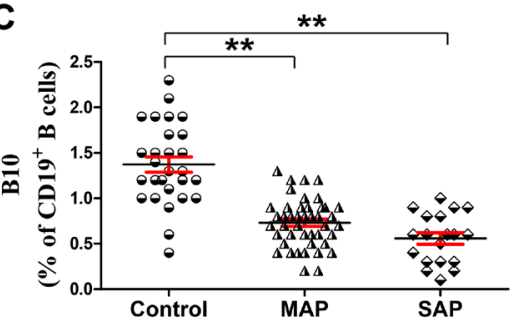

D

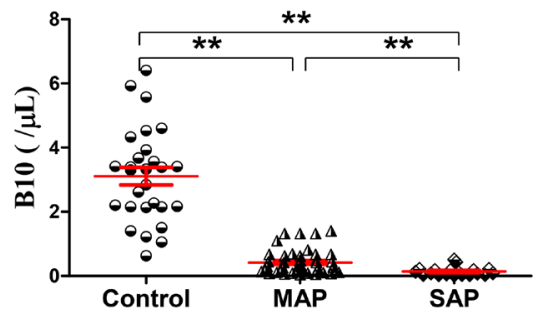

E

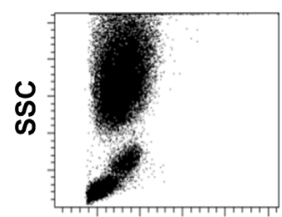

FSC

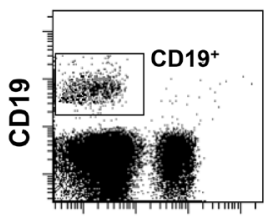

CD3

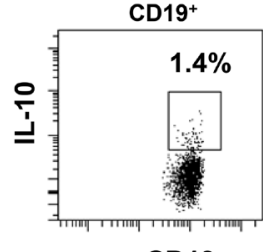

CD19

F

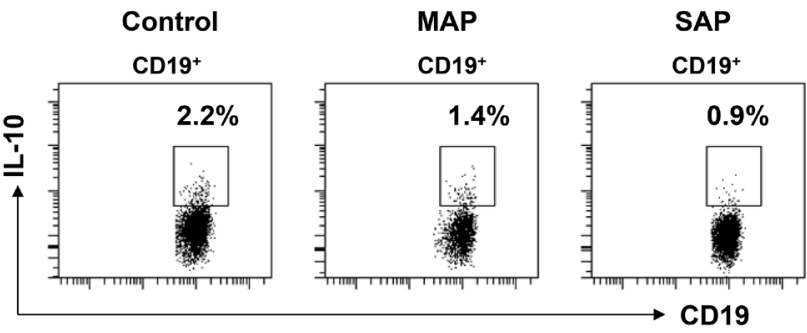

G

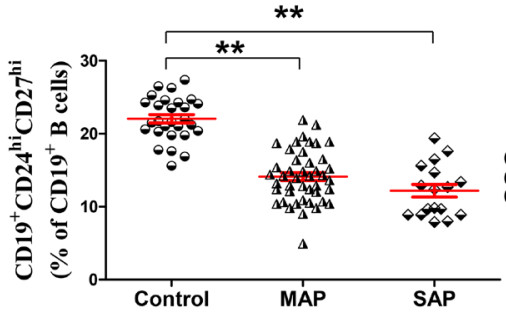

I
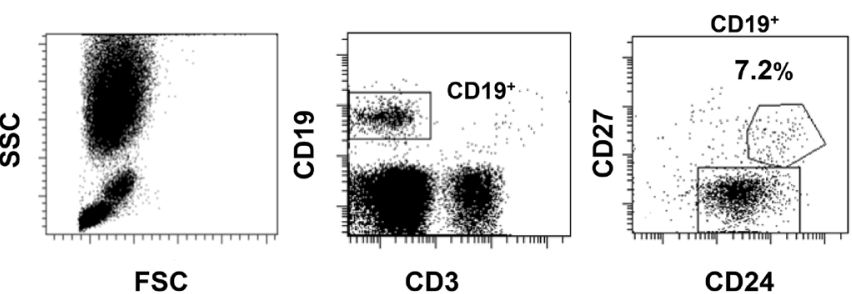

H

J
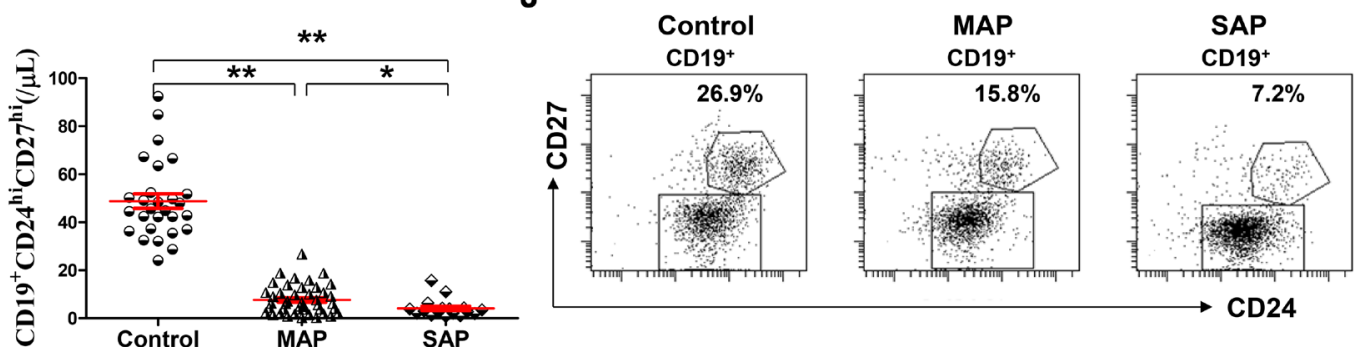

$\rightarrow \mathrm{CD} 24$

Figure 1: Decreased levels of $\mathrm{B} 10$ or $\mathrm{CD} 19^{+} \mathrm{CD} 24^{\mathrm{hi}} \mathrm{CD} 27^{\text {hi }}$ cells in patients with AP. Graph shows show cumulative data of the frequencies $(\mathbf{A}, \mathbf{C})$ of and numbers (B, D) of $\mathrm{CD} 19^{+}$and B10 cells in healthy individuals $(n=21)$, MAP patients $(n=46)$ and SAP patients $(n=17)$. (E) Representative flow cytometry plot depicts the gating strategy for B10 cells. (F) Representative dot plots of B10 cells from one healthy individual, one MAP patient and one SAP patient are shown. Graphs show cumulative data of the frequencies (G) and numbers (H) of circulating $\mathrm{CD} 19^{+} \mathrm{CD} 24^{\mathrm{hi}} \mathrm{CD} 27^{\text {hi }}$ cells. (I) Representative flow cytometry plot depicts the gating strategy for $\mathrm{CD} 19^{+} \mathrm{CD} 24^{\text {hi }} \mathrm{CD} 27^{\text {hi }}$ cells. $(\mathbf{J})$ Representative dot plots of $\mathrm{CD} 19^{+} \mathrm{CD} 24^{\text {hi }} \mathrm{CD} 27^{\text {hi }}$ cells from one healthy individual, one MAP patient and one SAP patient are shown. ${ }^{*} P<0.05 ;{ }^{* *} P<0.01$. 
organ dysfunction. As previously reported [21], our results showed that the serum levels of IL-6, IL-10, IL-17, TNF- $\alpha$ and TGF- $\beta$ were all increased in patients with MAP and SAP compared with the corresponding levels in healthy individuals (all $P<0.001$, Figure 6A-6C, E ,F); these levels were actually increased along with AP severity, and a significant difference was observed between patients with MAP and SAP (all $P<0.05$ ). However, the IFN- $\gamma$ levels in AP patients were not different from the levels in healthy individuals (Figure 6D). The time course of the change in cytokine levels of six patients with MAP and SAP is shown in Figure 6G-6L. In patients with MAP, the levels of IL-6, IL-10, IL-17, TNF- $\alpha$ and TGF- $\beta$ decreased from day 1 to day 7 (Figure 6K). In patients with SAP, the levels of all the studied cytokines remained stable except for the levels of IFN- $\gamma$ which increased over time (Figure 6J).

\section{Dynamic longitudinal observation of $\mathrm{B} 10$ or $\mathrm{CD}_{19}+\mathrm{CD24}{ }^{\text {hi }} \mathrm{CD} 27^{\text {hi }}$ cells in patients with $\mathrm{AP}$}

To observe the dynamic longitudinal changes in B10, CD $19^{+} \mathrm{CD} 24^{\mathrm{hi}} \mathrm{CD} 27^{\mathrm{hi}}$ cells, other immune cells and
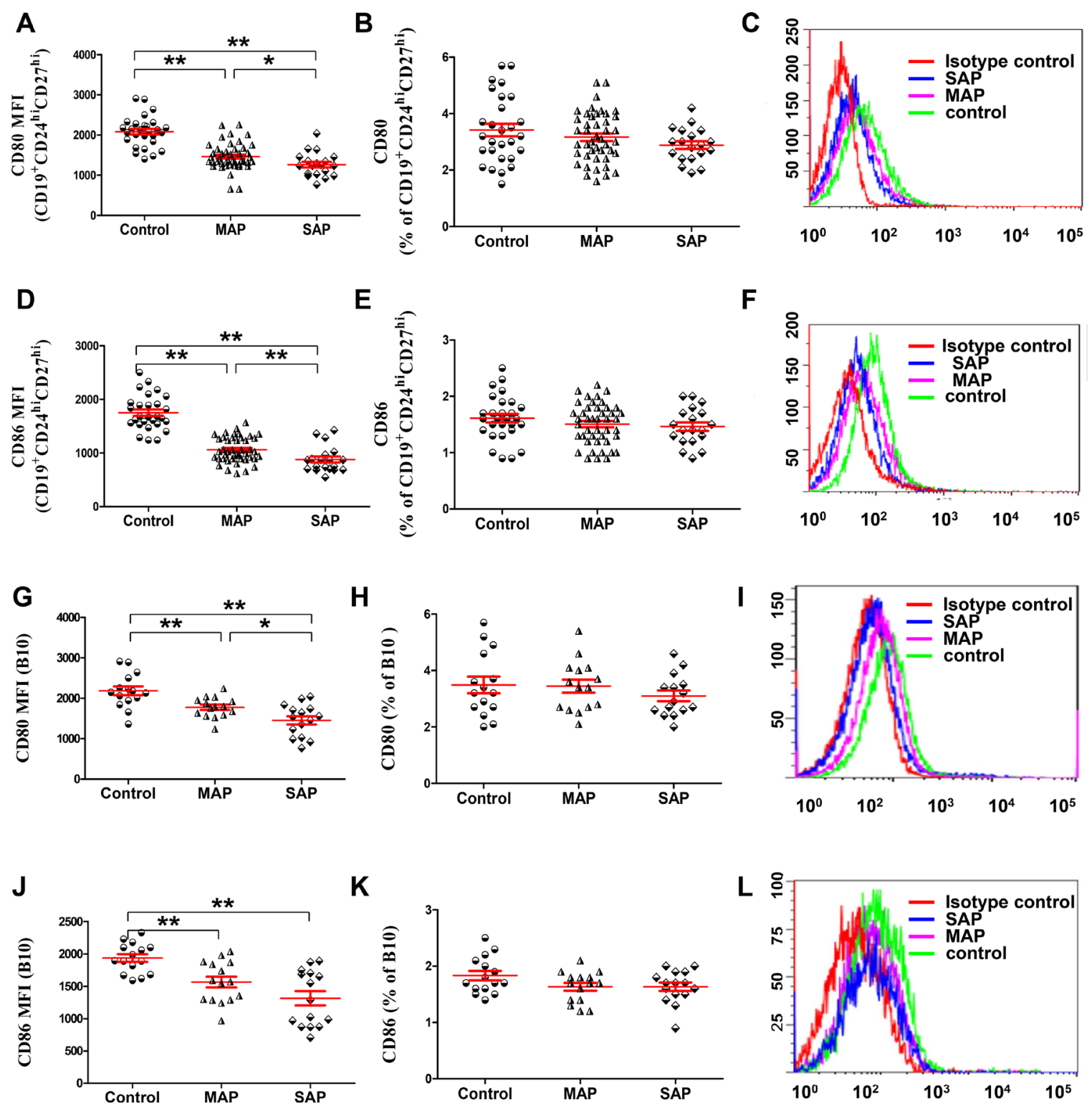

Figure 2: The lower MFI of CD80 and CD86 on B10 and CD19+CD24 ${ }^{\text {hi }}$ CD27 ${ }^{\text {hi }}$ cells in patients with AP. Graphs show the cumulative data on the MFI and frequencies of CD80 (A, B) and CD86 (D, E) on CD19 ${ }^{+} \mathrm{CD} 24^{\text {hi }} \mathrm{CD} 27^{\text {hi }}$ cells from healthy individuals $(n=$ 21), MAP patients $(n=46)$ and 17 SAP patients $(n=17)$. Representative expression of CD80 $(\mathbf{C})$ and CD86 (F) on CD19+CD24 ${ }^{\text {hi }} \mathrm{CD} 27^{\text {hi }}$ cells from one healthy individual, one MAP patient and one SAP patient are shown. Graphs show the cumulative data on the MFI and frequencies of CD80 $(\mathbf{G}, \mathbf{J})$ and $\operatorname{CD} 86(\mathbf{H}, \mathbf{K})$ on B10 cells from healthy individuals $(n=15)$, MAP patients $(n=15)$ and SAP patients $(n=$ 15). Representative expression of CD80 (I) and CD86 (L) on B10 cells from one healthy individual, one MAP patient and one SAP patient are shown. ${ }^{*} P<0.05,{ }^{* *} P<0.01$. 
A

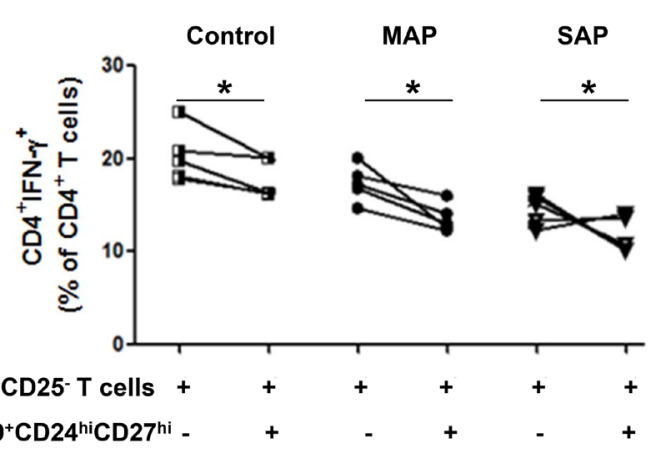

B

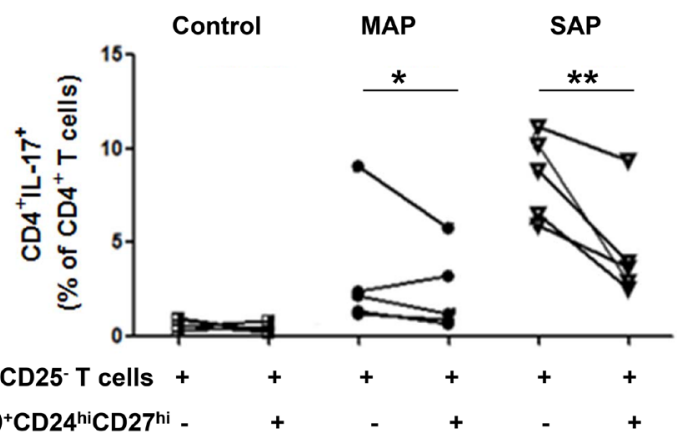

D

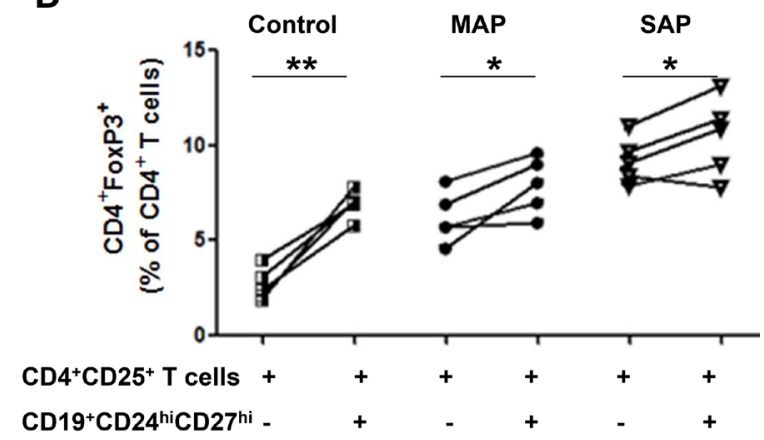

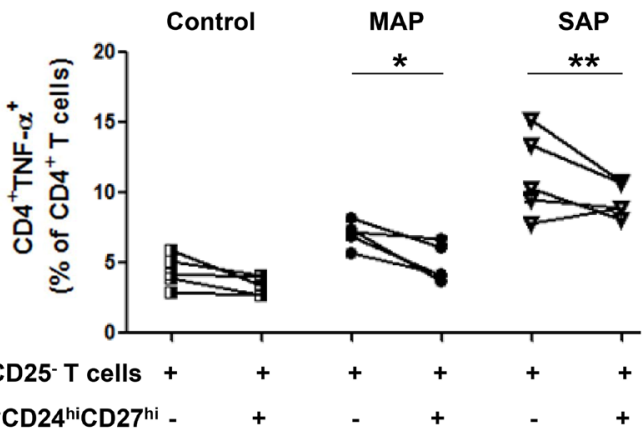
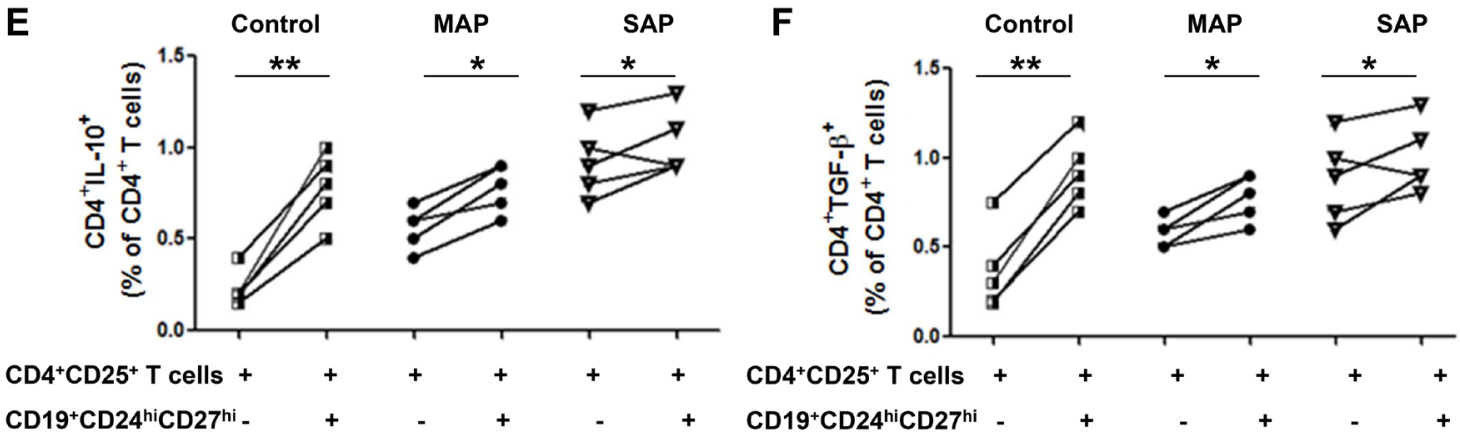

G

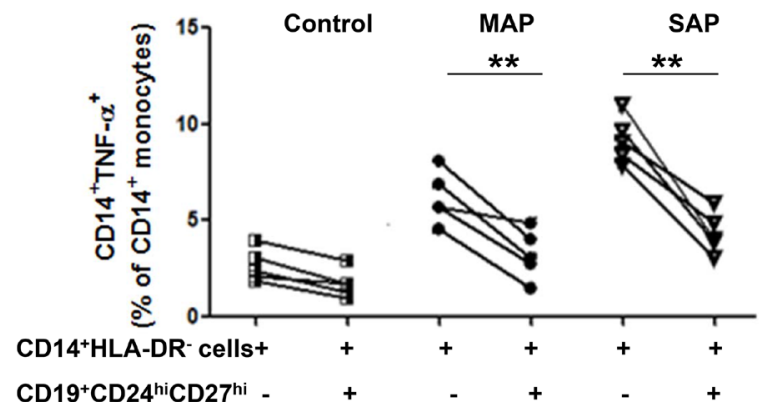

Figure 3: $\mathrm{CD} 19^{+} \mathrm{CD} 24^{\text {hi }} \mathrm{CD} 27^{\text {hi }}$ cells from AP patients suppress the cytokine productions of $\mathrm{CD}^{+} \mathrm{T}$ cells and $\mathrm{CD}_{14}{ }^{+}$monocytes and have impaired ability to induce Tregs response. FACS -sorted $\mathrm{CD} 19^{+} \mathrm{CD} 24^{\mathrm{hi}} \mathrm{CD} 27^{\mathrm{hi}}$ cells were cultured 1:1 with $\mathrm{CD} 4^{+} \mathrm{CD} 25^{-} \mathrm{T}$ cells, $\mathrm{CD} 4^{+} \mathrm{CD} 25^{+} \mathrm{T}$ cells or $\mathrm{CD} 14^{+} \mathrm{HLA}-\mathrm{DR}$-monocytes from healthy individuals $(n=5)$ and patients with MAP $(n$ $=5)$ and SAP $(n=5)$. Intracellular levels of IFN- $\gamma$, IL-17, TNF- $\alpha$, IL-10, FoxP3, TGF- $\beta$ in CD4 $4^{+}$T cells and TNF- $\alpha$ in CD14 monocytes were measured by flow cytometry. Graphs show the frequencies of CD4 $4^{+} \mathrm{IFN}-\gamma^{+}(\mathbf{A}), \mathrm{CD} 4^{+} \mathrm{IL}-17^{+}(\mathbf{B})$ and $\mathrm{CD} 4^{+} \mathrm{TNF}-\alpha^{+}(\mathbf{C})$ before or after $\mathrm{CD} 4^{+} \mathrm{CD} 25^{-} \mathrm{T}$ cells coculture with $\mathrm{CD} 19^{+} \mathrm{CD} 24^{\text {hi }} \mathrm{CD} 27^{\text {hi }}$ cells. Graphs show the frequencies of $\mathrm{CD} 4^{+} \mathrm{FoxP} 3^{+}(\mathbf{D}), \mathrm{CD} 4^{+} \mathrm{IL}-10^{+}(\mathbf{E})$ and CD4 $4^{+} \mathrm{TGF}_{-} \beta^{+}(\mathbf{F})$ before or after $\mathrm{CD} 4{ }^{+} \mathrm{CD} 25^{+} \mathrm{T}$ cells coculture with $\mathrm{CD} 19^{+} \mathrm{CD} 24^{\text {hi }} \mathrm{CD} 27^{\text {hi }}$ cells. (G) Graphs show the frequencies of CD14 $4^{+}$NF- $\alpha^{+}$before or after CD14 HLA-DR'monocytes coculture with CD19+CD24 $4^{\text {hi }} \mathrm{CD} 27^{\text {hi }}$ cells. ${ }^{*} P<0.05,{ }^{* *} P<0.01$. 
A

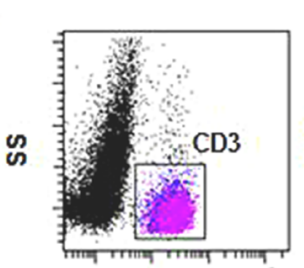

CD3

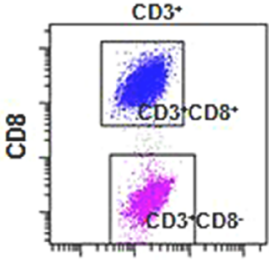

CD3

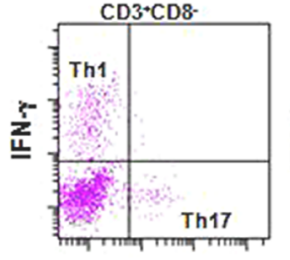

IL-17

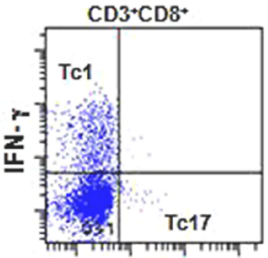

IL-17
B

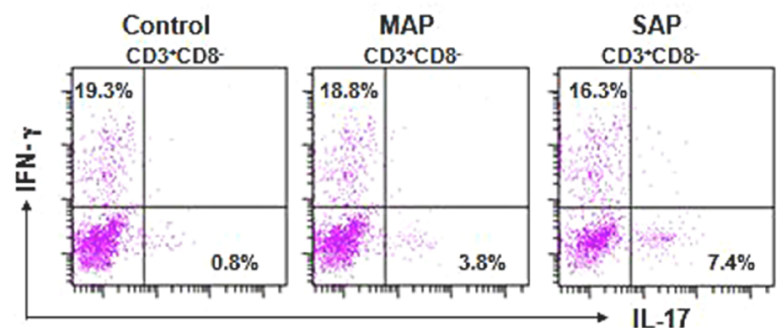

C

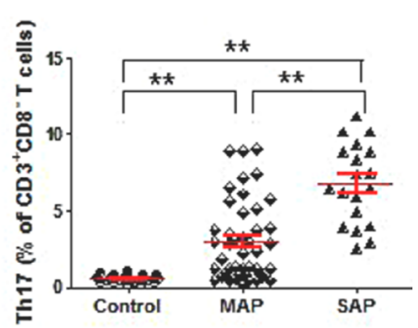

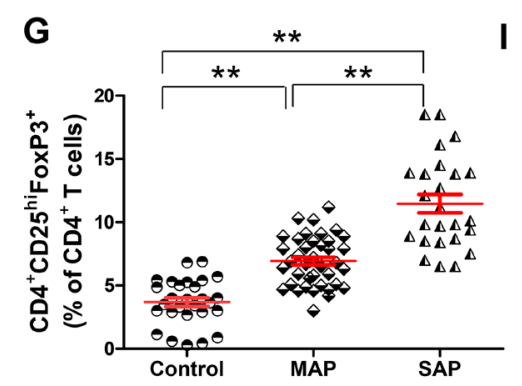
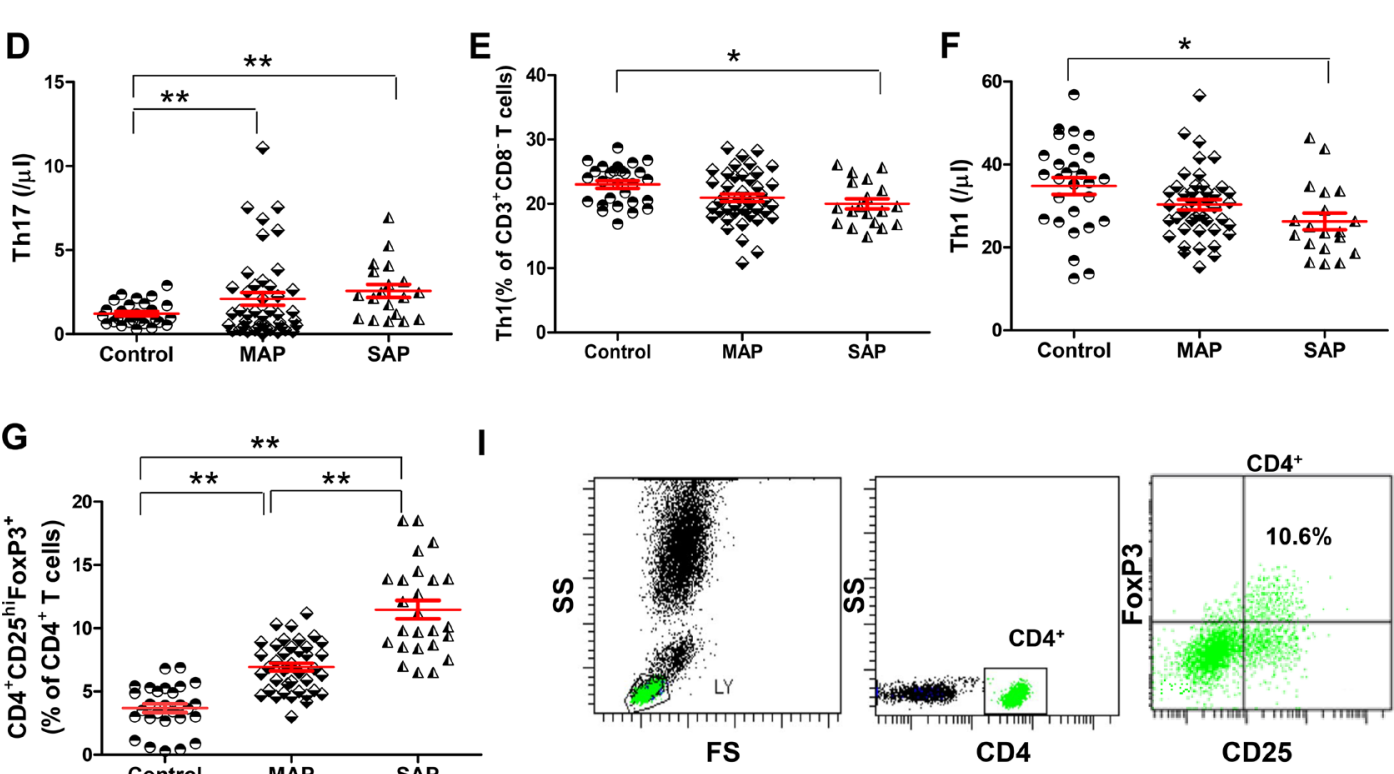

H
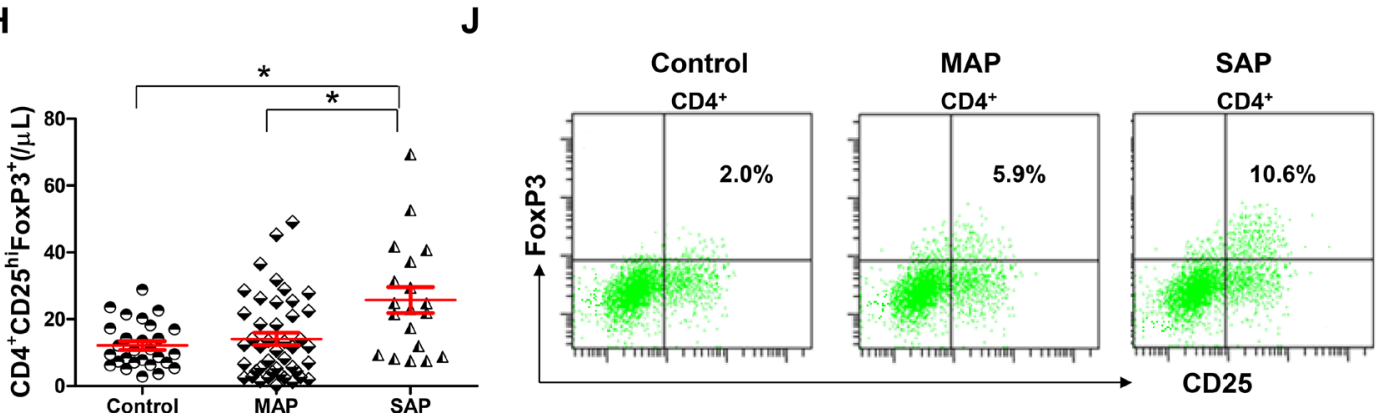

Figure 4: Elevated levels of $\mathrm{Th} 17$ cells and $\mathrm{CD}^{+} \mathrm{CD}^{+} 5^{\text {hiFoxP3}}{ }^{+}$Tregs and decreased levels of $\mathrm{Th} 1$ cells in patients with AP. (A) Representative flow cytometry plot depicts the gating strategy for Th17, Th1, Tc17 and Tc1 cells. (B) Representative dot plots of Th1 and Th17 cells from one healthy individual, one MAP patient and one SAP patient are shown. Graphs show cumulative data on the frequencies and numbers of Th17 (C-D), Th1 cells $(\mathbf{E}-\mathbf{F})$ and $\mathrm{CD} 4^{+} \mathrm{CD} 25^{\mathrm{hi}} \mathrm{FoxP} 3^{+}$Tregs $(\mathbf{G}-\mathbf{H})$ from healthy individuals $(n=21)$, MAP patients $(n=46)$ and SAP patients $(n=17)$. (I) Representative flow cytometry plot depicts the gating strategy for $\mathrm{CD} 4{ }^{+} \mathrm{CD} 25^{\text {hi }} \mathrm{FoxP} 3^{+}$Tregs. (J) Representative dot plots of $\mathrm{CD} 4{ }^{+} \mathrm{CD} 25^{\text {hi }} \mathrm{FoxP}^{+}$Tregs from one healthy individual, one MAP patient and one SAP patient are shown. ${ }^{*} P<0.05,{ }^{* *} P<0.01$. 
inflammatory markers during the progression of AP, we analyzed six patients with MAP and six patients with SAP from day 1 to day 7. As the disease progressed, B10 and $\mathrm{CD} 19^{+} \mathrm{CD} 24^{\mathrm{hi}} \mathrm{CD} 27^{\mathrm{hi}}$ cells were significantly increased, Th17 cells, CD14 ${ }^{+}$HLA-DR ${ }^{\text {low/- }}$ cells, CD64 index and CRP decreased after an initial rise from day 1 to day 7 in patients with MAP while these indexes remained stable in patients with SAP (Figure 7A, 7B, 7D, 7F, 7G, 7H). $\mathrm{CD}_{1}{ }^{+}$and Th1 cells remained stable over time in both groups (Figure 7C, 7F).

\section{B10 and $\mathrm{CD} 19^{+} \mathrm{CD} 24^{\mathrm{hi}} \mathrm{CD} 27^{\mathrm{hi}}$ cells are correlated with the severity index, inflammatory markers and cytokines in patients with AP}

To determine whether the numbers of B10 and $\mathrm{CD} 19^{+} \mathrm{CD} 24^{\mathrm{hi}} \mathrm{CD} 27^{\mathrm{hi}}$ cells are inversely correlated with AP severity, we investigated the correlation between $\mathrm{B} 10$ or $\mathrm{CD} 19^{+} \mathrm{CD} 24^{\mathrm{hi}} \mathrm{CD} 27^{\text {hi }}$ cells with the severity index, inflammatory markers and cytokines in patients with AP on day 3. Interestingly, we found that, to some extent, the numbers of $\mathrm{B} 10$ or $\mathrm{CD} 19^{+} \mathrm{CD} 24^{\mathrm{hi}} \mathrm{CD} 27^{\text {hi }}$ cells were inversely correlated with APACHE II score, CRP, CD64 index, IL-6, IL-17 and TNF- $\alpha$ levels in patients with AP (Figure 8A-8L). No significant difference was observed between $\mathrm{B} 10$ or $\mathrm{CD} 19^{+} \mathrm{CD} 24^{\mathrm{hi}} \mathrm{CD} 27^{\text {hi }}$ cells and IL-10, IFN- $\gamma$ and TGF- $\beta$ levels at any time point in either group (Supplementary Figure 2A-2F). Taken together, our findings showed that B10 and $\mathrm{CD} 19^{+} \mathrm{CD} 24^{\mathrm{hi}} \mathrm{CD} 27^{\mathrm{hi}}$ cells were significantly decreased in correlation with the severity index, inflammatory markers and cytokines, and therefore, the detection of these cells may be useful for the prediction of the development of SAP.

\section{Diagnostic accuracy analysis of B10 or $\mathrm{CD}^{+}{ }^{+} \mathrm{CD}^{2} 4^{\text {hi }} \mathrm{CD27}{ }^{\text {hi }}$ cells}

Subsequently, ROC analyses were performed to determine accuracy of $\mathrm{B} 10$ or $\mathrm{CD} 19^{+} \mathrm{CD} 24^{\text {hi }} \mathrm{CD} 27^{\text {hi }}$ cells for the prediction of the development of SAP. The analyses were initially limited to patients with MAP and SAP immediately after admission to the hospital. The diagnostic utility of
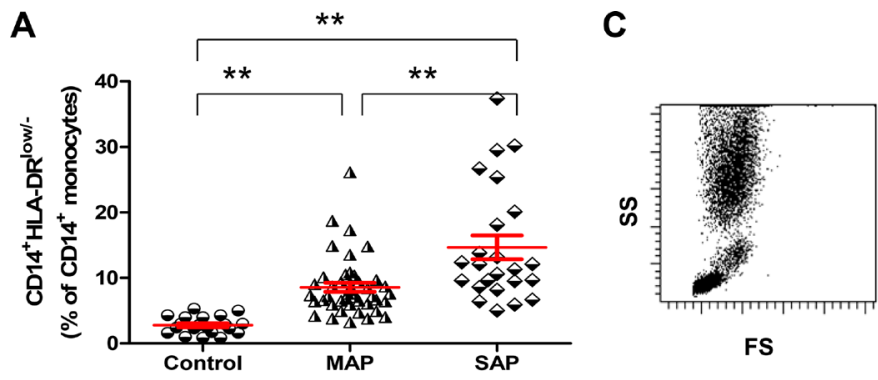

FS

$\mathbf{D}$
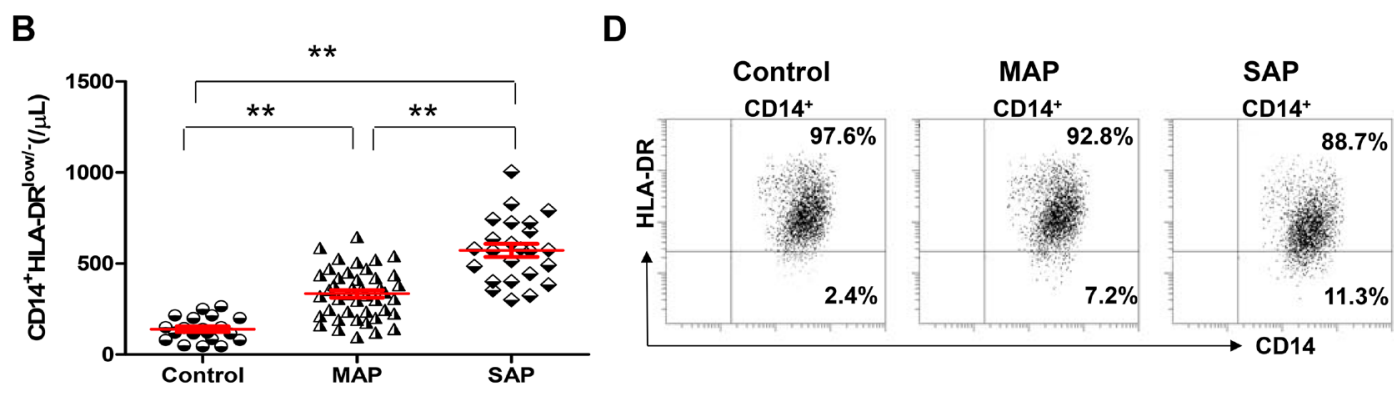

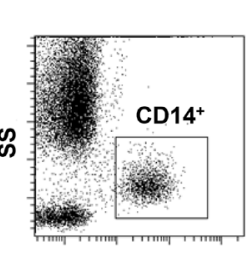

CD14

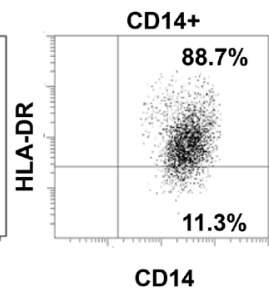

D14

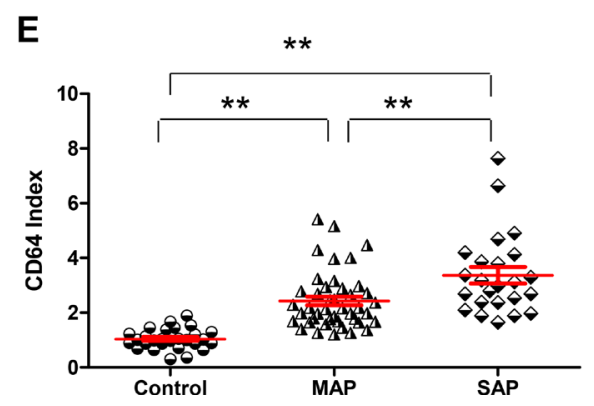

Figure 5: CD14 ${ }^{+}$HLA-DR ${ }^{\text {Low/- }}$ cells and CD64 index are elevated in patients with AP compared with healthy individuals. Graphs show the frequencies $(\mathbf{A})$ and numbers $(\mathbf{B})$ of CD14 HLA-DR $^{\text {Low/ }}$ cells from healthy individuals $(n=21)$, MAP patients $(n=46)$ and SAP patients $(n=17)$. (C) Representative flow cytometry plot depicts the gating strategy for CD14 ${ }^{+} H L A-D R^{\text {Low/- }}$ cells. (D) Representative dot plots of CD14 ${ }^{+}$HLA-DR ${ }^{\text {Low/- }}$ cells from one healthy individual, one MAP patient and one SAP patient are shown. (E) Graphs show CD64 Index from healthy individuals $(n=21)$, MAP patients $(n=46)$ and SAP patients $(n=17) .{ }^{*} P<0.05,{ }^{* *} P<0.01$. 
the detection of $\mathrm{B} 10$ or $\mathrm{CD} 19^{+} \mathrm{CD} 24^{\mathrm{hi}} \mathrm{CD} 27^{\mathrm{hi}}$ cells for the prediction of SAP was comparable with APACHE II score, CRP and CD14 ${ }^{+}$HLA-DR ${ }^{\text {low/ }}$. A B10 count below $0.1366 / \mu \mathrm{L}$ predicted SAP to a greater degree with a sensitivity of $84 \%$ and a specificity of $53 \%$, whereas a count of CD $19^{+} \mathrm{CD} 24^{\mathrm{hi}} \mathrm{CD} 27^{\mathrm{hi}}$ cells below $4.146 / \mu \mathrm{L}$ predicted SAP to a greater degree with a sensitivity of $74 \%$ and a specificity of $51 \%$. The value of the area under ROC curve (AUC) for B10 was 0.856 [95\% confidence interval (CI) 0.767-0.9372], which was higher than that for CRP $(0.741,95 \%$ CI 0.687-0.895), APACHE II score (0.762, $95 \%$ CI $0.703-0.899), \mathrm{CD} 19^{+} \mathrm{CD} 24^{\mathrm{hi}} \mathrm{CD} 27^{\mathrm{hi}}(0.743$, $95 \%$ CI $0.679-0.892)$ and CD14 ${ }^{+} \operatorname{HLA}_{-}-\mathrm{DR}^{\text {low/ }}(0.745,95 \%$ CI 0.684-0.897) (Figure 9).

\section{DISCUSSION}

Early stratification of AP severity, especially severe cases, is clinically important for the determination of optimal or intensive treatment to improve outcomes [22]. Clinical scoring systems (APACHE II score and Ranson score) and several serum markers (CRP, procalcitonin, IL-6, and IL-8) have been used to assess the severity of AP [23-24]. However, these approaches have limitations. Conventional severity scores consist of multiple factors (Ranson, 11 factors; and APACHE II, 14 factors) and are complicated, and they may therefore be difficult to accomplish in clinical practice when patients are admitted
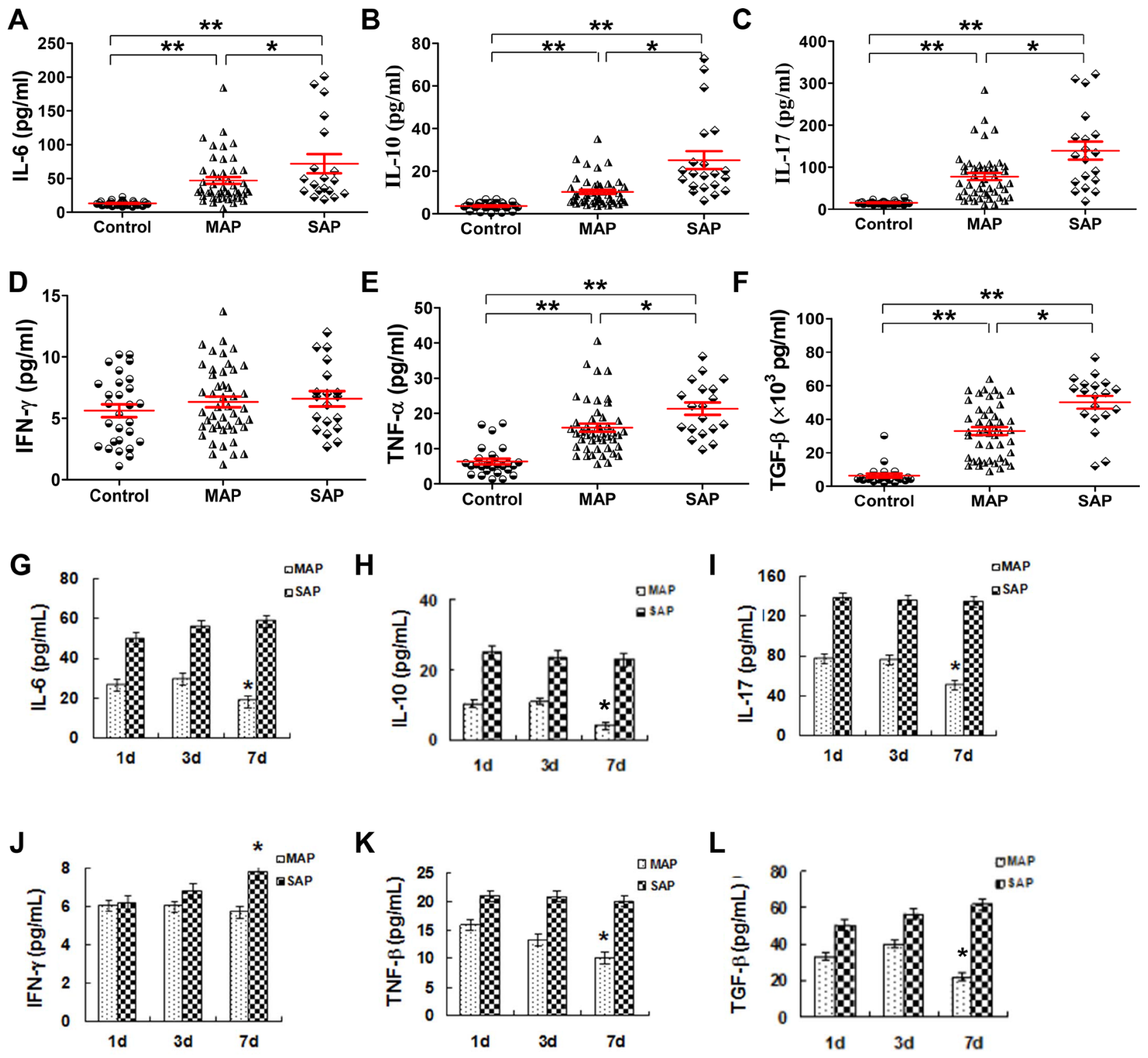

Figure 6: Serum cytokines except for IFN- $\gamma$ increase in patients with AP. Cytokines in serum samples collected from healthy individuals $(n=21)$, MAP patients $(n=46)$ and SAP patients $(n=17)$ were measured by CBA. Graphs show the cumulative data of the levels of IL-6 (A), IL-10 (B), IL-17 (C), IFN- $\gamma(\mathbf{D})$, TNF- $\alpha(\mathbf{E})$ and TGF- $\beta$ (F) in healthy individuals $(n=21)$, MAP patients $(n=46)$ and SAP patients $(n=17)$. Graphs show the time course of the changes in the levels of IL-6 (G), IL-10 (H), IL-17 (I), IFN- $\gamma(\mathbf{J})$, TNF- $\alpha(\mathbf{K})$ and TGF- $\beta(\mathbf{L})$ from patients with MAP $(n=6)$ and $\operatorname{SAP}(n=6) .{ }^{*} P<0.05,{ }^{* *} P<0.01$. 
to a hospital. Taken together, novelpathogenically relevant biomarkers for the early prediction of disease severity are needed.

Immunologic impairment in the early phase of AP may be linked to an increased susceptibility to subsequent infection and the development of septic complications. The phenomenon of immunoparalysis, defined as downregulation of HLA-DR expression on monocytes, and disequilibrium of various helper $\mathrm{T}$ cell subsets are usually associated with exaggerated anti-inflammatory responses and high bacterial complications in patients with sepsis, burns, cirrhosis, or AP $[14,15,25]$. These results indicate that immune cells are involved in the pathophysiological process and determine the severity of AP. Regulatory B cells, which are increased in human inflammatory and autoimmune diseases, were previously ascribed with the capacity to suppress autoimmune inflammation, chronic $\mathrm{T}$ cell inflammation, and possibly antitumor immunity [26, 27]. Regulatory B cells suppress immune responses via the release of IL-10 or TGF- $\beta$, the inhibition of the release of IFN- $\gamma$ and TNF- $\alpha$ and the induction of Tregs populations as well as interaction with target cells via molecules expressed on the cell surface, such as CD80, CD86 [18,
26-30]. But our study showed a significant reduction in lymphocytes, CD19, B10 and $\mathrm{CD} 19^{+} \mathrm{CD} 24^{\mathrm{hi}} \mathrm{CD} 27^{\mathrm{hi}}$ cells in AP patients, which was consistent with the results reported by Qiu et al. [31]. Further, we detected lower MFI of CD 80 and CD 86 on B10 and CD $19^{+} \mathrm{CD} 24^{\text {hi }} \mathrm{CD} 27^{\text {hi }}$ cells in patients with $\mathrm{AP}$ and $\mathrm{CD} 19^{+} \mathrm{CD} 24^{\mathrm{hi}} \mathrm{CD} 27^{\mathrm{hi}}$ cells from AP patients suppressed the cytokine productions of $\mathrm{CD}^{+} \mathrm{T}$ cells and $\mathrm{CD} 14^{+}$monocytes, but the ability of $\mathrm{CD} 19^{+} \mathrm{CD} 24^{\mathrm{hi}} \mathrm{CD} 27^{\mathrm{hi}}$ cells to induce Tregs response were impaired. These results showed that abnormal numbers and functions of $\mathrm{B} 10$ and $\mathrm{CD} 19^{+} \mathrm{CD} 24^{\mathrm{hi}} \mathrm{CD} 27^{\text {hi }}$ cells may be important contributors to immune dysfunction in AP and may be associated with the degree of organ failure and high mortality in patients with SAP.

It is now established that B lymphocytes contribute directly to enhanced $\mathrm{T}$ cell activation and differentiation (e.g., Th1 and Th17) via the production of proinflammatory cytokines (such as IL-6 and TNF- $\alpha$ ) [32]. Th17 cells and related cytokines (IL-6, IL-17) have been used to assess severity in studies of AP [10, 15, 33-35]. IL-17 promotes the differentiation of B cells into antibody-secreting plasma cells in autoimmune diseases [36]. TNF- $\alpha$, which is released by many immune cells
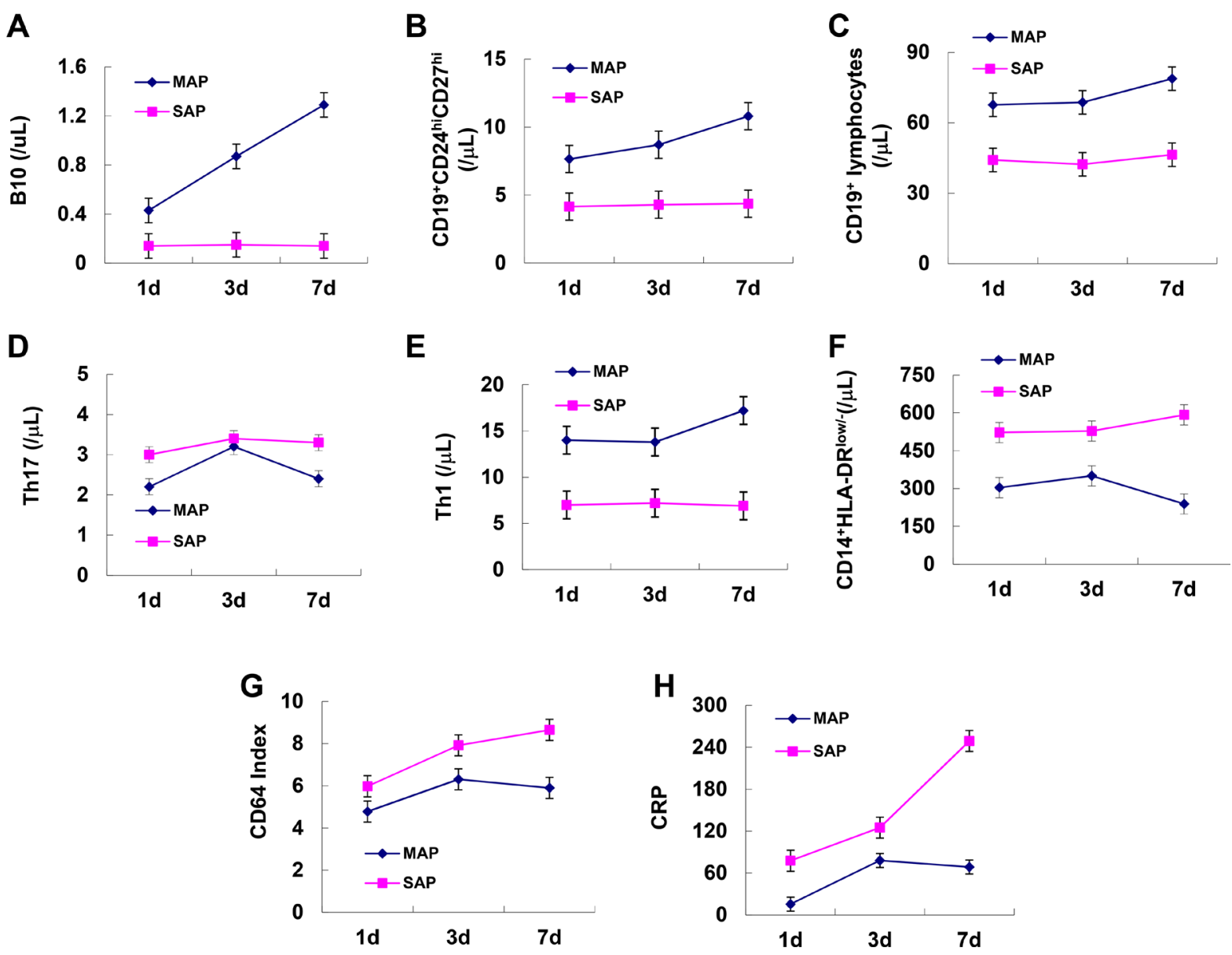

Figure 7: Dynamic longitudinal changes in $\mathrm{B} 10$ and $\mathrm{CD} 19^{+} \mathrm{CD} 24^{\mathrm{hi}} \mathrm{CD} 27^{\mathrm{hi}}$ cells and inflammatory markers in patients with AP. Graphs show dynamic longitudinal changes in the numbers of B10 (A), CD19 ${ }^{+} \mathrm{CD} 24^{\text {hi }} \mathrm{CD} 27^{\mathrm{hi}}(\mathbf{B}), \mathrm{CD} 19^{+}(\mathbf{C}), \mathrm{Th} 17$ (D) Th1 (E), CD14 ${ }^{+} \operatorname{HLA}_{-D R}{ }^{\text {Low/- }}(\mathbf{F})$, CD64 Index $(\mathbf{G})$ and $\operatorname{CRP}(\mathbf{H})$ in patients with $\operatorname{MAP}(n=6)$ and $\operatorname{SAP}(n=6)$. 

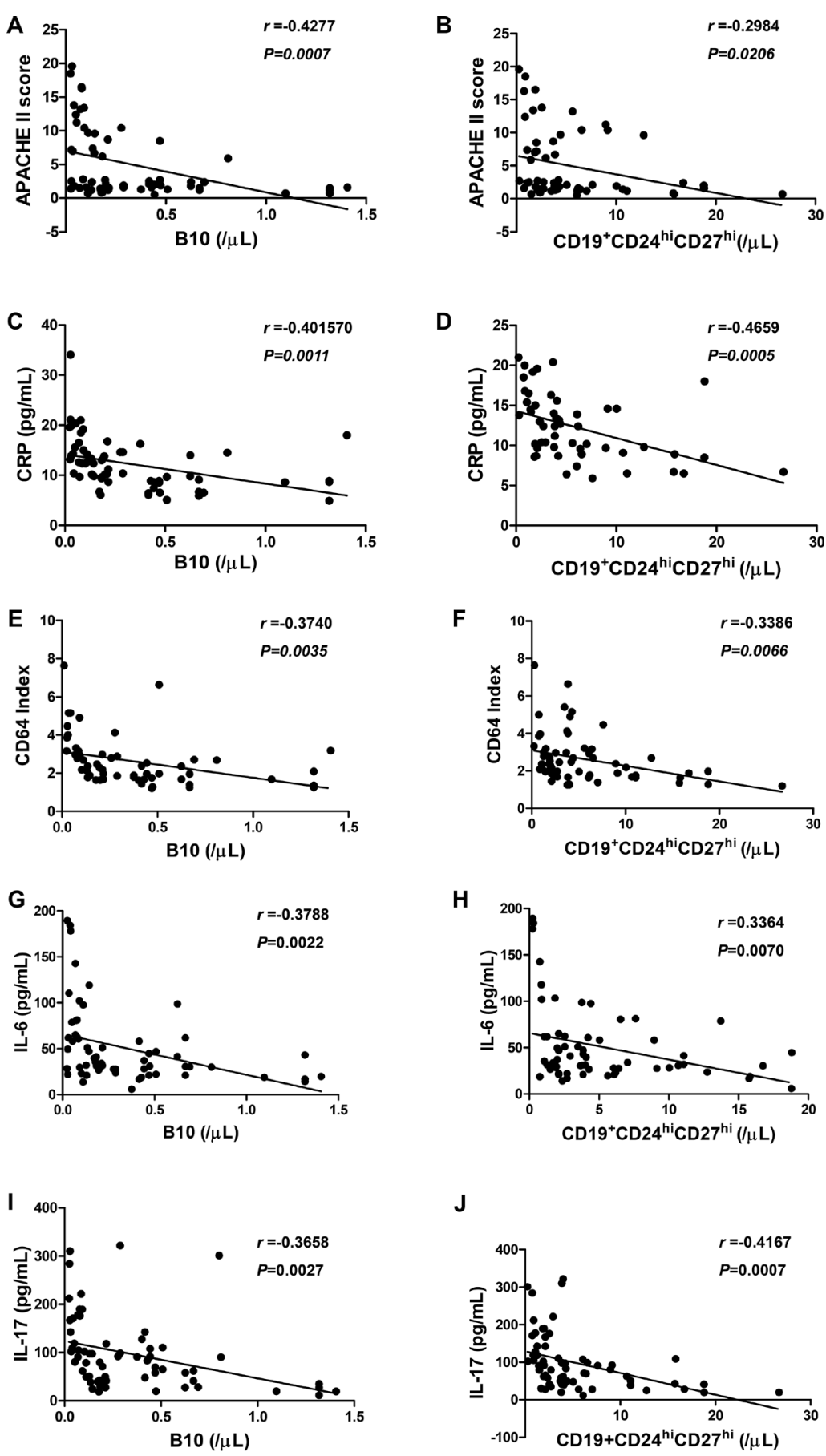

$\mathbf{J}$
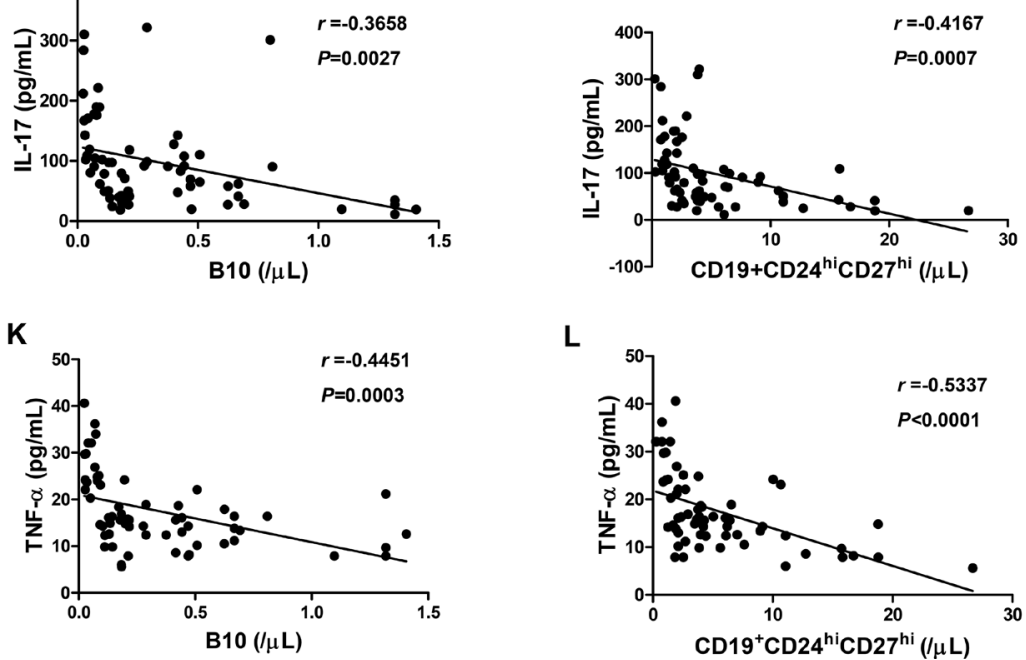

Figure 8: The correlation between $\mathrm{B} 10$ or $\mathrm{CD} 19^{+} \mathrm{CD} 24^{\text {hi }} \mathrm{CD} 27^{\text {hi }}$ cells and inflammatory markers and serum levels of cytokines in patients with AP. Spearman's rank correlation test was performed to compare the respective correlations between B10 or $\mathrm{CD} 19^{+} \mathrm{CD} 24^{\mathrm{hi}} \mathrm{CD} 27^{\mathrm{hi}}$ cells and APACHE II score $(\mathbf{A}, \mathbf{B}), \mathrm{CRP}(\mathbf{C}, \mathbf{D})$, CD64 Index $(\mathbf{E}, \mathbf{F})$, IL-6 $(\mathbf{G}, \mathbf{H})$, IL-17 (I, J) and TNF- $\alpha(\mathbf{K}, \mathbf{L})$ in patients with AP. R represents a correlation coefficient; a negative $\mathrm{R}$ value indicates a negative correlation. 
such as $\mathrm{CD} 14^{+} \mathrm{HLA}-\mathrm{DR} \mathrm{low}^{\text {lo }}$ monocytes, is associated with a more severe course of AP, including SIRS and MODS [37]. Just as IL-17 and IL-6 contribute to the differentiation of Th17 cells, IL-10 and TGF- $\beta$ contribute to the differentiation of regulatory cells $[17,18,27]$. In response to certain stimuli, any B cell could potentially differentiate into a "regulatory B cell," which can then suppress local inflammation [38]. In our study, serum IL6 , IL-10, IL-17, TNF- $\alpha$ and TGF- $\beta$ levels were increased in patients with AP at admission and were then decreased on day 7 in patients with MAP, whereas the levels remained stable, with the exception of IFN- $\gamma$, in patients with SAP. Function analyses found $\mathrm{CD} 19^{+} \mathrm{CD} 24^{\mathrm{hi}} \mathrm{CD} 27^{\mathrm{hi}}$ cells from patients with AP suppressed the release of IFN- $\gamma$, TNF- $\alpha$ and IL-17 in CD4 ${ }^{+}$CD25- $\mathrm{T}$ cells and the release of TNF- $\alpha$ in $\mathrm{CD} 14^{+} \mathrm{HLA}^{-\mathrm{DR}}{ }^{-}$cells, but were unable to induce Tregs response in $\mathrm{CD} 4^{+} \mathrm{CD} 25^{+} \mathrm{T}$ cells efficiently. The reduced numbers and abnormal function of $\mathrm{B} 10$ and $\mathrm{CD} 19^{+} \mathrm{CD} 24^{\mathrm{hi}} \mathrm{CD} 27^{\mathrm{hi}}$ cells promoted the cytokine productions of $\mathrm{CD}^{+} \mathrm{T}$ cells and $\mathrm{CD}^{+} 4^{+}$monocytes and induced $\mathrm{CD}^{+} \mathrm{FoxP}^{+}$Tregs expansion, which could further produce a large number of inflammatory factors and cause severe inflammatory damages. Th17 cells further promote the release of pro-inflammatory cytokines such as IL-17, IL-6, and chemokines to expand the inflammatory response, which may eventually cause further immune disorders and lead to SIRS and even death. B10 as well as $\mathrm{CD} 19^{+} \mathrm{CD} 24^{\mathrm{hi}} \mathrm{CD} 27^{\text {hi }}$ cells started to increased with time in patients with MAP and suppressed inflammation and restored immune balance, while in patients with SAP they continued to deceased, then aggravated inflammation leads to SIRS and MODS. We conclude that $\mathrm{B} 10$ and $\mathrm{CD} 19^{+} \mathrm{CD} 24^{\text {hi }} \mathrm{CD} 27^{\text {hi }}$ cells might play a protective role in AP. Further, in our AP patients, $\mathrm{B} 10$ and $\mathrm{CD} 19^{+} \mathrm{CD} 24^{\mathrm{hi}} \mathrm{CD} 27^{\text {hi }}$ cells reflected the general inflammatory response and predicted the AP severity. However, the identity of the specific cytokines that inhibit the development of $\mathrm{B} 10$ and $\mathrm{CD} 19^{+} \mathrm{CD} 24^{\mathrm{hi}} \mathrm{CD} 27^{\text {hi }}$ cells requires further study.

To assess the diagnostic value of $\mathrm{B} 10$ and $\mathrm{CD} 19^{+} \mathrm{CD} 24^{\mathrm{hi}} \mathrm{CD} 27^{\mathrm{hi}}$ cells, we compared the numbers of $\mathrm{B} 10$ and $\mathrm{CD} 19^{+} \mathrm{CD} 24^{\mathrm{hi}} \mathrm{CD} 27^{\text {hi }}$ cells on day 3 with

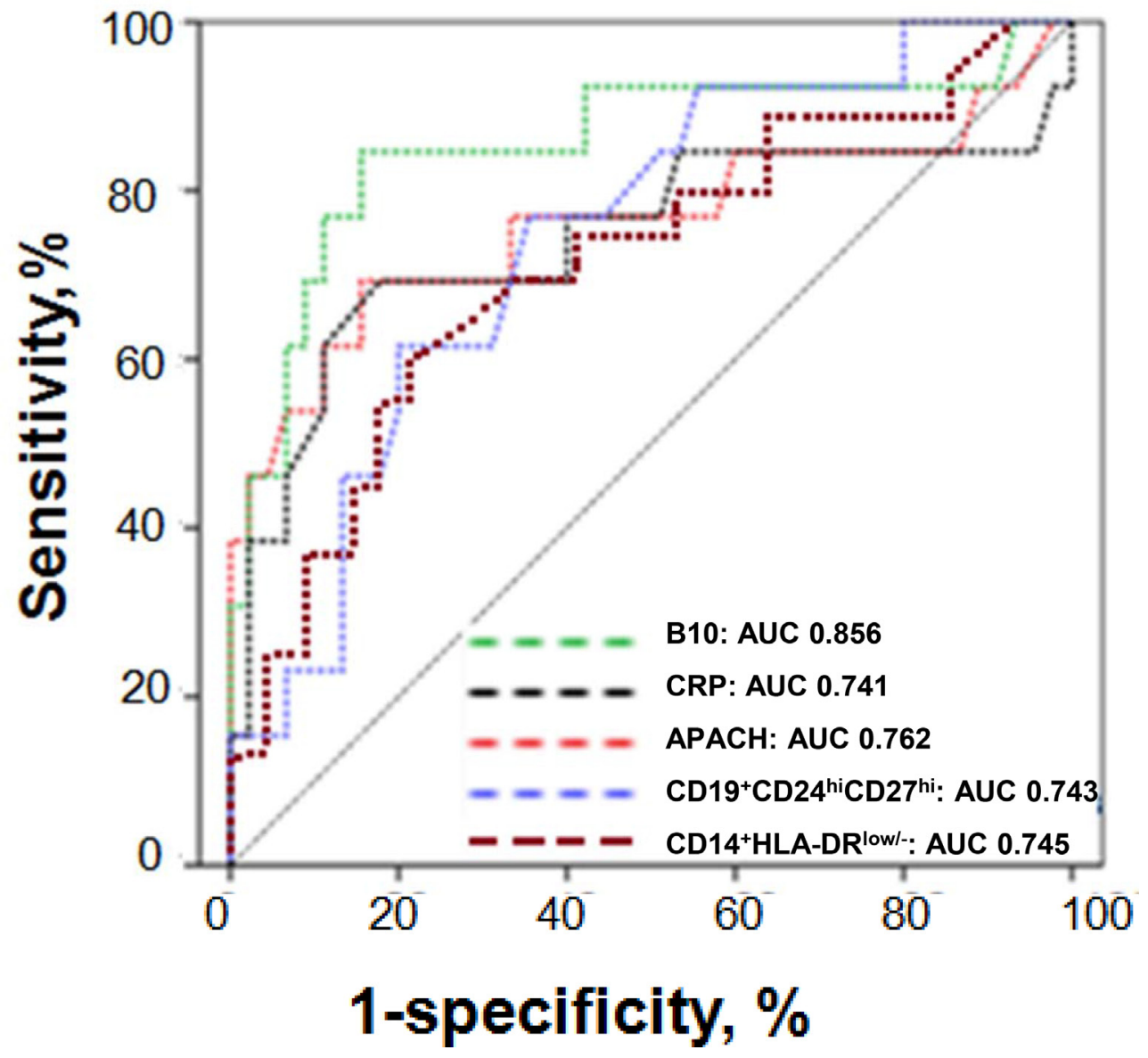

Figure 9: ROC curves for B10 or $\mathbf{C D 1 9}{ }^{+} \mathbf{C D 2 4} 4^{\text {hi }} \mathbf{C D 2} 7^{\text {hi }}$ cells in the prediction of SAP. ROC curves for B10 or CD19 $\mathrm{CD} 24^{\text {hi }} \mathrm{CD} 27^{\text {hi }}$ cells measured within $24 \mathrm{~h}$ from the onset of AP in the prediction of SAP in comparison to other laboratory tests associated with AP severity. The selected cut-off values are highlighted, and AUC with $95 \%$ confidence intervals and $P$-values for the difference in the AUC from AUC $=0.5$ are shown on the graphs. The values of the AUC for each test are shown on the graph. The diagonal line is the line of no-discrimination. 
APACHE II score, CRP, CD64 index and cytokines. Our previous report showed that CD64 index and CD14 ${ }^{+} \mathrm{HLA}-$ $\mathrm{DR}^{\text {low/- }}$ cells were increased in patients with AP and were highly correlated with APACHE II score [25]. In this study, we noticed that $\mathrm{B} 10$ and $\mathrm{CD} 19^{+} \mathrm{CD} 24^{\mathrm{hi}} \mathrm{CD} 27^{\mathrm{hi}}$ cells were highly inversely correlated with APACHE II score, CRP , CD64 index and the serum levels of IL-6, IL-17 and TNF- $\alpha$. Moreover, ROC analyses revealed that B10 or $\mathrm{CD} 19^{+} \mathrm{CD} 24^{\mathrm{hi}} \mathrm{CD} 27^{\mathrm{hi}}$ cells predicted the development of SAP, which indicates that B10 and $\mathrm{CD} 19^{+} \mathrm{CD} 24^{\mathrm{hi}} \mathrm{CD} 27^{\mathrm{hi}}$ cells may be early markers that can be used to predict the development of SAP.

To the best of our knowledge, this is the first report on the diagnostic utility of B10 and $\mathrm{CD} 19^{+} \mathrm{CD} 24^{\mathrm{hi}} \mathrm{CD} 27^{\mathrm{h}}$ cells for the early prediction of AP severity. Our data were based on a limited number of patients, especially those with SAP. For this reason, we were unable to reliably assess the diagnostic utility of $\mathrm{B} 10$ and $\mathrm{CD} 19^{+} \mathrm{CD} 24^{\mathrm{hi}} \mathrm{CD} 27^{\mathrm{hi}}$ cells for the prediction of SAP. Nonetheless, B10 and $\mathrm{CD} 19^{+} \mathrm{CD} 24^{\mathrm{hi}} \mathrm{CD} 27^{\mathrm{hi}}$ cells were significantly decreased in patients with AP, especially in those with SAP, and were negatively associated with the severity of the disease. If this is confirmed in further investigations, the detection of B 10 and $\mathrm{CD} 19^{+} \mathrm{CD} 24^{\mathrm{hi}} \mathrm{CD} 27^{\mathrm{hi}}$ cells might be a practical way to improve the early assessment of AP severity.

\section{MATERIALS AND METHODS}

\section{Subjects}

The study group comprised 63 patients with AP at Zhejiang's Province People's Hospital and 21 agematched healthy individuals. AP was diagnosed according to the presence of typical symptoms, such as abdominal pain, and more than three times the normal levels of serum amylase and lipase. All patients fulfilled the criteria for AP and were retrospectively categorized into MAP ( $n=$ $46)$ or SAP $(n=17)$ according to the Atlanta classification [39]. The characteristics of the patients are shown in Table 1. Patients who were admitted later than $24 \mathrm{~h}$ from the onset of pain due to AP were excluded. Furthermore, patients with chronic pancreatitis, chronic liver diseases (cirrhosis or viral hepatitis), neoplasms of any origin and those treated with immunosuppressants were excluded. Blood samples were immediately obtained from each patient after admission and also on the third and seventh days. All patients received supportive management using intravenous fluid without oral alimentation. Parenteral antibiotics were prescribed for prevention of infection in patients with SAP. An echo-guided or CT-guided aspiration for Gram stain and bacterial culture was performed when infected necrosis or pancreatic abscesses were suspected. Percutaneous drainage or surgical management was performed if infected necrosis or pancreatic abscess was present. All patients were observed until they died or were followed up at the outpatient clinic if they were discharged. None of the patients received drugs affecting immune function .

This study was approved by the Ethics Committee of the Zhejiang's Province People's Hospital. Informed consent was obtained from all individual participants included in the study.

\section{Cell isolation}

PBMCs were isolated from blood samples using a Ficoll-Hypaque density gradient centrifugation method. $\mathrm{CD} 19^{+} \mathrm{CD} 24^{\mathrm{hi}} \mathrm{CD} 27^{\mathrm{hi}}$ cells, CD $4^{+} \mathrm{CD} 25^{-} \mathrm{T}$ cells (effector $\mathrm{T}$ cells), $\mathrm{CD} 4^{+} \mathrm{CD} 25^{+} \mathrm{T}$ cells (Tregs) and CD $14^{+}$HLADR- cells from five healthy individuals, five patients with MAP and five patients with SAP were purified using a fluorescence-activated cell sorting (FACS) Aria cell sorter (Becton Dickinson, Palo Alto, CA, USA) based on their expression of CD4, CD25 or CD19, CD24, CD27 and CD14, HLA-DR. Cell purity was confirmed $>95 \%$ by flow cytometry.

\section{Flow cytometric analysis}

With respect to the surface marker staining, fresh peripheral blood was tested using the following monoclonal antibodies: APC-CD3 (SK7), FITC-CD19 (J4.119), PerCP-CD27 (L128), PerCP-cy5.5-CD24 (ML5), PE-CD80 (MAB104), PerCP-cy5.5-CD80 (MAB104), PE-CD86 (HA5.2B7), PerCP-cy5.5-CD86 (HA5.2B7), PerCP-cy5.5-CD8 (SK1), PE-CD14 (RMO52), FITCHLA-DR (Immu-357) and FITC-CD64 (22). After the cells were incubated with the antibodies for $30 \mathrm{~min}$ at $4^{\circ} \mathrm{C}$ in the dark, they were lysed with $\mathrm{NH}_{4} \mathrm{CL}$ solution. Data acquisition and analysis were performed using BD FACSCanto II flow cytometry with FACSDiva software (BD Biosciences, San Diego, CA, USA). The fluorescence intensity of CD64 expression on neutrophils and lymphocytes was measured as the MFI as a linearized value of a log scale. CD64 index is calculated by the ratio of the MFI of the granulocytes to that of the lymphocytes.

For the detection of $\mathrm{T}$ helper-secreted intracellular cytokines, peripheral blood mononuclear cells (PBMCs, 2 $\times 10^{6}$ cells $/ \mathrm{mL}$ ) were stimulated with phorbol 12-myristate 13-acetate (PMA) (50 ng/mL, Sigma-Aldrich) plus ionomycin (1 mg/mL, Sigma-Aldrich) for 5 hours in the presence of monensin. After membrane staining for CD3 and CD8, the cells were fixed and permeabilized using a Cytofix/Cytoperm kit (BD Biosciences, San Diego, CA, USA ) and were stained with PE-conjugated IL-17F (O79$289)$ and FITC-conjugated IFN- $\gamma(\mathrm{B} 27)$. $\mathrm{CD}^{+} \mathrm{CD}^{-}$cells, but not $\mathrm{CD}^{+} \mathrm{CD}^{+}$cells, were defined as $\mathrm{T}$ helper cells, due to the downregulation of surface CD4 after stimulation with PMA and ionomycin.

Intracellular IL-10 analysis was performed as previously described [40]. PBMCs were resuspended $\left(2 \times 10^{6}\right.$ cells $\left./ \mathrm{mL}\right)$ in RPMI1640 medium in the presence 
of CpG (ODN 2006, $10 \mathrm{mg} / \mathrm{mL}$; InvivoGen, San Diego, CA) and CD40 ligand (CD40L, $1 \mathrm{mg} / \mathrm{mL}$; BD Biosciences); PMA (50 ng/mL, sigma), ionomycin (1 mg/ $\mathrm{mL}$, sigma), and brefeldin A (5 mg/mL, BioLegend) were added for the last 5 hours of incubation. After membrane staining for CD3 and CD19, the cells were fixed and permeabilized using a Cytofix/Cytoperm kit and stained with a PE-conjugated IL-10 (JES5-19F1).

\section{Cytokine immunoassays}

The serum levels of IL-6, IL-10, IL-17, IFN- $\gamma$ and TNF- $\alpha$ were determined using BD $^{\mathrm{TM}}$ Cytometric Bead Array Human Th1 / Th2 / Th17 kits (BD Bioscience, San Diego, CA, USA). The minimum detectable levels for IL6 , IL-10, IL-17, IFN- $\gamma$ and TNF- $\alpha$ were $2.4,4.5,7.6,3.7$ and $3.8 \mathrm{pg} / \mathrm{mL}$, respectively. TGF- $\beta$ levels were measured by enzyme-linked immunosorbent assay according to the manufacturer's instructions. All measurements were obtained in duplicate and according to the protocols provided by the manufacturers.

\section{Function analyses of $\mathrm{CD} 19^{+} \mathrm{CD} 24^{\mathrm{hi}} \mathrm{CD} 27^{\mathrm{hi}}$ cells}

Isolated $\mathrm{CD}^{+} \mathrm{CD} 25^{-} \mathrm{T}$ cells $\left(1.5 \times 10^{5}\right)$ or $\mathrm{CD} 4^{+} \mathrm{CD} 25^{+} \mathrm{T}$ cells $\left(1.5 \times 10^{5}\right)$ were cultured either alone or $1: 1$ with purified autologous $\mathrm{CD} 19^{+} \mathrm{CD} 24^{\text {hi }} \mathrm{CD} 27^{\text {hi }}$ cells $\left(1.5 \times 10^{5}\right)$ in complete RPMI 1640, L-glutamine, and NaHCO3 supplemented with $10 \%$ FCS and penicillin/ streptomycin $(100 \mathrm{U} / \mathrm{mL})$ in 96-well U-bottom plates in the presence of medium or anti-CD3 $(1 \mu \mathrm{g} / \mathrm{mL})$ plus anti-CD28 $(1 \mu \mathrm{g} / \mathrm{mL})$ for $72 \mathrm{~h}$, and with PIB (PMA + ionomycin + brefeldin A) added in the last $5 \mathrm{~h}$ as described elsewhere. Cells were then surface-stained CD4-APC (4S. B3) permeabilized, stained intracellularly for IFN- $\gamma$ (FITC, 4S.B3), IL-17F (PE, N49-653), Forkhead box P3 (FoxP3, PE, 259C/C7), IL-10 (PE, JES5-19F1), TGF- $\beta$ (PE, TW49E7) and TNF- $\alpha$ (Alexa Fluo488, MAb11) and analyzed by flow cytometry. Isolated CD14 ${ }^{+} \mathrm{HLA}^{-D R^{-}}$cells $\left(1.5 \times 10^{5}\right)$ were cultured either alone or $1: 1$ with purified autologous $\mathrm{CD} 19^{+} \mathrm{CD} 24^{\mathrm{hi}} \mathrm{CD} 27^{\text {hi }}$ cells $\left(1.5 \times 10^{5}\right)$ in complete RPMI 1640, L-glutamine, and NaHCO3 supplemented with 10\% FCS and penicillin /streptomycin $(100 \mathrm{U} / \mathrm{mL})$ in 96-well U-bottom plates in the presence of medium for $72 \mathrm{~h}$, and with PIB (PMA + ionomycin+ brefeldin A) added in the last $5 \mathrm{~h}$ as described elsewhere. Cells were then surface-stained CD14, permeabilized, stained intracellularly for TNF- $\alpha$ and analyzed by flow cytometry.

\section{Statistical analysis}

Statistical analyses were performed by Student's $t$-test for the comparison of sample means between two groups or by one-way analysis of variance for comparisons of more than two groups. The Pearson product-moment correlation coefficient was used to examine the relationship between two continuous variables. The Wilcoxon matched paired rank test was used for matched paired samples. $P$ values $<0.05$ were considered to be statistically significant. The data were shown as the median (range) unless otherwise indicated. All analyses were performed using the Statistical Package for the Social Sciences statistical software for Windows, version 11.5 (SPSS Inc., Chicago, IL, USA).

\section{Clinical assessment}

Written informed consent was obtained from all the enrolled patients and healthy individuals.

\section{ACKNOWLEDGMENTS}

Q.L.N designed the experiments and wrote the manuscript. Z.Y.L takes responsibility for the integrity of the data and the accuracy of the data analysis. Y.Q.H and Y.J.D conducted Flow cytometry and ELISA technique. L.Q. and S.R.H assessed the severity of AP. All authors read and approved the final manuscript.

\section{CONFLICTS OF INTEREST}

The authors declare no conflicts of interest.

\section{FUNDING}

This study was partly supported by the Zhejiang Provincial Natural Science Fund (No: LY12H16019), and the Zhejiang Provincial Program for the Cultivation of High-level Innovative Health Talents (No: 2012).

\section{REFERENCES}

1. Frossard JL, Steer ML, Pastor CM. Acute pancreatitis. Lancet. 2008; 371:143-152.

2. Banks PA, Freeman ML. Practice guidelines in acute pancreatitis. Am J Gastroenterol. 2006; 10:2379-2400.

3. Dervenis C, Johnson CD, Bassi C, Bradley E, Imrie CW, McMahon MJ, Modlin I. Diagnosis, objective assessment of severity, and management of acute pancreatitis. Santorini consensus conference. Int J Pancreatol. 1999; 25:195-210.

4. Pongprasobchai S, Jianjaroonwong V, Charatcharoenwitthaya P, Komoltri C, Tanwandee T, Leelakusolvong S, Pausawasdi N, Srikureja W, Chainuvati S, Prachayakul V, Manatsathit S, Kachintorn U. Erythrocyte sedimentation rate and C-reactive protein for the prediction of severity of acute pancreatitis. Pancreas. 2010; 39:1226-30.

5. Ng PC, Li K, Wong RP, Chui KM, Wong E, Fok TF. Neutrophil CD64 expression: a sensitive diagnostic marker for late-onset nosocomial infection in very low birthweight infants. Pediatr Res. 2002; 51:296-303. 
6. Streimish I, Bizzarro M, Northrup V, Wang C, Renna S, Koval N, Li FY, Ehrenkranz R, Rinder HM, Bhandari V. Neutrophil CD64 as a diagnostic marker in neonatal sepsis. Pediatr Infect Dis J. 2012; 31:777-781.

7. Mentula P, Kylänpää-Bäck ML, Kemppainen E, Takala A, Jansson SE, Kautiainen H, Puolakkainen P, Haapiainen R, Repo H. Decreased HLA (human leucocyte antigen)DR expression on peripheral blood monocytes predicts the developmentof organ failure in patients with acute pancreatitis. Clin Sci (Lond). 2003; 105:409-417.

8. Papachristou GI, Clermont G, Sharma A, Yadav D, Whitcomb DC. Risk and markers of severe acute pancreatitis. Gastroenterol Clin North Am. 2007; 36:277-296.

9. Rau BM. Predicting severity of acute pancreatitis. Curr Gastroenterol Rep. 2007; 9:107-115.

10. Mofidi R, Patil PV, Suttie SA, Parks RW. Risk assessment in acute pancreatitis. Br J Surg. 2009; 96:137-50.

11. Pooran N, Indaram A, Singh P, Bank S. Cytokines (IL-6, IL-8, TNF): early and reliable predictors of severe acute pancreatitis. J Clin Gastroenterol. 2003; 37:263-266.

12. Ueda T, Takeyama $Y$, Yasuda $T$, Matsumura N, Sawa H, Nakajima T, Ajiki T, Fujino Y, Suzuki Y, Kuroda Y. Significant elevation of serum interleukin-18 levels in patients with acute pancreatitis. J Gastroenterol. 2006; 41:158-165.

13. Schutte K, Malfertheiner P. Markers for predicting severity and progression of acute pancreatitis. Best Pract Res Clin Gastroenterol. 2008; 22:75-90.

14. Schmitz-Winnenthal H, Pietsch DH, Schimmack S, Bonertz A, Udonta F, Ge Y, Galindo L, Specht S, Volk C, Zgraggen K, Koch M, Büchler MW, Weitz J, Beckhove P. Chronic pancreatitis is associated with disease-specific regulatory T-cell responses. Gastroenterology. 2010; 138:1178-1188.

15. Uehara S, Gothoh K, Handa H, Tomita H, Tomita Y. Immune function in patients with acute pancreatitis. J Gastroenterol Hepatol. 2003; 18:363-70.

16. Małgorzata CD, Stanisław G. Serum IL-17 concentration in acute pancreatitis with the emphasis on the severity of the disease. Przegląd Gastroenterologiczny. 2009; 4:31-40.

17. Iwata Y, Matsushita T, Horikawa M, Dilillo DJ, Yanaba K, Venturi GM, Szabolcs PM, Bernstein SH, Magro CM, Williams AD, Hall RP, St Clair EW, Tedder TF. Characterization of a rare IL-10-competent B-cell subset in humans that parallels mouse regulatory B10 cells. Blood. 2011; 117:530-41.

18. Blair PA, Noreña LY, Flores-Borja F, Rawlings DJ, Isenberg DA, Ehrenstein MR, Mauri C. CD $19{ }^{+} \mathrm{CD} 24^{\text {hi }} \mathrm{CD} 38^{\text {hi }} \mathrm{B}$ cells exhibit regulatory capacity in healthy individuals but are functionally impaired in systemic Lupus Erythematosus patients. Immunity. 2010; 32:129-140.

19. Flores-Borja F, Bosma F, Ng D, Reddy V, Ehrenstein $\mathrm{MR}$, Isenberg DA, Mauri C. CD $19^{+} \mathrm{CD} 24^{\text {hi }} \mathrm{CD} 38^{\text {hi }} \mathrm{B}$ cells maintain regulatory $\mathrm{T}$ cells while limiting $\mathrm{TH} 1$ and $\mathrm{TH} 17$ differentiation. Sci Transl Med. 2013; 5:ra23.
20. Carter NA, Vasconcellos R, Rosser EC, Tulone C, MunozSuano A, Kamanaka M, Ehrenstein MR, Flavell RA, Mauri C. Mice lacking endogenous IL-10-producing regulatory B cells develop exacerbated disease and present with an increased frequency of Th1/Th17 but a decrease in regulatory T cells. J. Immunol. 2011; 186:5569-5579.

21. Yamauchi J, Shibuya K, Sunamura M, Arai K, Shimamura H, Motoi F, Takeda K, Matsuno S. Cytokine modulation in acute pancreatitis. J Hepatobiliary Pancreat Surg. 2001; 8:195-203.

22. Lankisch PG, Apte M, Banks PA. Acute pancreatitis. Lancet. 2015; 32:81-92.

23. Knaus WA, Draper EA, Wagner DP, Zimmerman JE. APACHE II: a severity of disease classification system. Crit Care Med. 1985; 13:818-829.

24. Cardoso FS, Ricardo LB, Oliveira AM, Canena JM, Horta DV, Papoila AL, Deus JR. C-reactive protein prognostic accuracy in acute pancreatitis: timing of measurement and cutoff points. Eur J Gastroenterol Hepatol. 2013; 25:784-89.

25. Qiu LN, Yu QH, Yu JD, Wang H, Zhou YL, Li Q, Wang GG, Huang XL. The prognostic value of CD14+ HLADRlow/- for evaluating the severity of acute pancreatitis. Chin J Microbiol Immunol. 2014; 34:620-23.

26. Candando KM, Lykken JM, Tedder TF. B10 cell regulation of health and disease. Immunol Rev. 2014; 259:259-72.

27. Wilde B, Thewissen M, Damoiseaux J, Knippenberg S, Hilhorst M, van Paassen P, Witzke O. Cohen Tervaert JW. Regulatory B cells in ANCA-associated vasculitis. Ann Rheum Dis. 2013; 72 :1416-9.

28. Mauri C, Bosma A. Immune regulatory function of B cells. Annu. Rev. Immunol. 2012; 30:221-241.

29. Lemoine S. Morva A, Youinou P, Jamin C. Human T cells induce their own regulation through activation of B cells. J. Autoimmun. 2011; 36: 228-238.

30. Guo Y, Cen Z, Wei B, Wu W, Zhou Q. Increased circulating interleukin 10-secreting B cells in patients with dilated cardiomyopathy. Int J Clin Exp Pathol. 2015; 8:8107-14.

31. Qiu Z, Yu P, Bai B, Hao Y, Wang S, Zhao Z, Hang Z, Wang Q, Guo M, Feng Q, Zhao Q. Regulatory B10 cells play a protective role in severe acute pancreatitis. Inflamm. Res. 2016; 65:647-654.

32. Hoffman W, Lakkis FG, Chalasani G. B cells, antibodies, and More. Clin J Am Soc Nephrol. 2016; 11:137-54.

33. Banchereau J, Pascual V, O'Garra A. From IL-2 to IL-37: the expanding spectrum of anti-inflammatory cytokines. Nat Immunol. 2012; 13:925-931.

34. Jia RR, Tang MC, Qiu L, Sun RQ, Cheng L, Ma XY, Yin GJ, Hu GY, Wang XP, Zhao Y. Increased Interleukin-23/17 Axis and C-reactive protein are associated with severity of acute pancreatitis in patients. Pancreas. 2015; 44:321-325.

35. Malleo G, Mazzon E, Siriwardena AK, Cuzzocrea S. Role of tumor necrosis factor-alpha in acute pancreatitis: from biological basis to clinical evidence. Shock. 2007; 28:130e40. 
36. Doreau A, Belot A, Bastid J, Riche B, Trescol-Biemont MC, Ranchin B, Fabien N, Cochat P, Pouteil-Noble C, Trolliet P, Durieu I, Tebib J, Kassai B, et al. Interleukin 17 acts in synergy with $\mathrm{B}$ cell-activating factor to influence B cell biology and the pathophysiology of systemic lupus erythematosus. Nat Immunol. 2009; 10:778-85.

37. Zhang DL, Li JS, Jiang ZW, Yu BJ, Tang XM, Zheng HM. Association of two polymorphisms of tumor necrosis factor gene with acute biliary pancreatitis. World J Gastroenterol. 2003; 9:824e8.

38. Rosser EC, Mauri C. Regulatory B cells: origin, phenotype, and function. Immunity. 2015; 42:607-12.
39. Banks PA, Bollen TL, Dervenis C, Gooszen HG, Johnson CD, Sarr MG, Tsiotos GG, Vege SS. Classification of acute pancreatitis-2012: revision of the Atlanta classification and definitions by international consensus. Gut. 2013; 62:102111.

40. Yoshizaki A, Miyagaki T, Dilillo DJ, Matsushita T, Horikawa M, Kountikov EI, Spolski R, Poe JC, Leonard WJ, Tedder TF. Regulatory B cells control T-cell autoimmunity through IL-21-dependent cognate interactions. Nature, 2012; 491:264-268. 